\title{
Variation in male reproductive system characters in Corydoradinae (Loricarioidei: Callichthyidae) reflects the occurrence of different lineages in this subfamily
}

\author{
Maria A. Spadella ${ }^{1}$, Simone P. Desan ${ }^{2}$, Teresa C. B. P. O. Henriques ${ }^{2}$ and \\ Claudio Oliveira ${ }^{3}$
}

Callichthyidae comprises a well-corroborated monophyletic group divided into two subfamilies: Corydoradinae and Callichthyinae. A recent proposal, based on molecular data, suggests that Corydoradinae is composed by nine monophyletic lineages, possibly genera. The species pertaining to those lineages have extensive modification in the size of genome, including diploid, tetraploid and octoploid species. Considering the occurrence of these monophyletic lineages and that the variations in DNA content may imply in significant alterations on the structure of spermatozoa, this study analyzed the morphology of the male reproductive system and the morphometry of the head of the spermatozoa of representatives of the nine lineages of Corydoradinae, seeking for particular characteristics of each lineage. Morphological data revealed a high intra-lineage variation, larger than that observed among species of different lineages. In contrast, morphometric data obtained for eight out of the nine lineages, revealed large congruency with the hypothesis that Corydoradinae is composed by different lineages. These results demonstrate that there is a correlation among variations in DNA content and the size of the spermatozoon head, thus providing additional subsides for the definition of the Corydoradinae lineages.

Keywords: Monophyly, Morphometry, Spermatozoa, Variations in DNA.

A família Callichthyidae compreende um grupo monofilético bem corroborado, dividida em duas subfamílias: Corydoradinae e Callichthyinae. Uma proposta recente, baseada em dados moleculares, sugeriu que a subfamília Corydoradinae é composta por nove linhagens, possivelmente gêneros. As espécies pertencentes a cada uma destas linhagens possuem extensivas modificações no tamanho do genoma, incluindo espécies diplóides, tetraplóides e octaplóides. Considerando a ocorrência dessas diferentes linhagens e que as extremas variações em conteúdo de DNA podem implicar em alterações significativas na estrutura dos espermatozoides, o presente estudo analisou a morfologia do sistema reprodutor masculino e a morfometria da cabeça dos espermatozoides de representantes das nove linhagens de Corydoradinae, procurando características particulares em cada uma. Os dados morfológicos revelaram a ocorrência de grande variação dentro das linhagens, maior que aquela observada entre espécies de diferentes linhagens. Diferentemente, os dados morfométricos obtidos para oito das nove linhagens revelaram grande congruência com a atual proposta para Corydoradinae. Estes resultados demonstram que há correlação entre as variações em conteúdo de DNA e o tamanho da cabeça dos espermatozoides, fornecendo, assim, subsídio adicional para a definição das nove linhagens de Corydoradinae.

Palavras-chave: Espermatozoides, Monofilia, Morfometria, Variações no DNA.

\section{Introduction}

The fish fauna of Central and South America continental waters is dominated in terms of taxonomic and biomass diversity by fishes from the superorder Ostariophysi, series Otophysi, reaching $73 \%$ of the species of this area, distributed among the orders Siluriformes, Characiformes and
Gymnotiformes (Burgess, 1989; Reis, 2003). Siluriformes comprehends an extremely large fish group, diverse and widely distributed, mainly in South America, Africa and south and Southeast Asia (Teugels, 1996; de Pinna, 1998; Arratia et al., 2003; Nelson et al., 2016). The number of valid siluriform species is approximately 3,720 , according to the Catalog of Fishes database (Eschmeyer, Fong, 2016).

${ }^{1}$ Disciplina de Embriologia, Faculdade de Medicina de Marília, Caixa Postal 2003, 17519-030 Marília, SP, Brazil. maspadella@gmail.com (corresponding author)

${ }^{2}$ Faculdade de Medicina de Marília, Caixa Postal 2003, 17519-030 Marília, SP, Brazil. (SPD) sisipask@hotmail.com, (TCBPOH) ovar62@ hotmail.com

${ }^{3}$ Departamento de Morfologia, Instituto de Biociências, UNESP, Caixa Postal 510, 18618-000 Botucatu, SP, Brazil. claudio@ibb.unesp.br 
Callichthyidae is one of the largest monophyletic group of siluriforms in the Neotropical region (de Pinna, 1998; Britto, 2003a; Ferraris, 2007), being the first natural group of siluriform recognized. It is divided into two subfamilies: Corydoradinae and Callichthyinae, considered monophyletic (Reis, 2003; Britto, 2003b). Shimabukuro-Dias et al. (2004), in a phylogenetic study of Callichthyidae based on sequences of mitochondrial genes, corroborate the monophyly of the family, as well as of the subfamilies. Corydoradinae includes around $90 \%$ of the diversity found in Callichthyidae, with about 188 valid species and more being described every year (Reis, 1998; Britto, 2003b; Eschmeyer, Fong, 2016).

Corydoradinae comprehends the genera Corydoras, Scleromystax and Aspidoras (Reis, 1998, 2003; Britto, 2003b) and, Shimabukuro-Dias et al. (2004) corroborate the non-monophyletism of Corydoras as previously suggested by Reis (1998) and Britto (2003b).

In a recent study, Alexandrou et al. (2011), based on the study of mitochondrial and nuclear DNA sequences, found that Corydoradinae is composed by at least nine lineages. The authors proposed that six of those nine lineages could represent new genera to keep monophyletic the genera Aspidoras, Corydoras and Scleromystax. The authors also discuss, from cytogenetic data, that the species from the different lineages have extensive genomic modifications, with chromosome complements varying from $2 \mathrm{n}=44$ to 144 , as well as genome size varying from 1.1 to 8.7 picograms (pg). Despite most of genomic variations among the lineages, the authors report that there is also significant variation within the lineages, frequently, among sister species. Alexandrou et al. (2011) also describe that, among the identified basal Corydoradinae lineages (lineages 1, 2 and 3 ), the size of genome varied from 0.51 to $0.94 \mathrm{pg} / \mathrm{DNA}$ by haploid nucleus, while on derived lineages (lineages from 4 to 9) a much larger variation was observed, from 1.4 until 4.8pg. The larger variations were found on lineages 6,7 and 9 (from 4.1 until $8.7 \mathrm{pg}$ ), suggesting that multiple independent polyploidy events may have occurred along the different branches of the proposed Corydoradinae phylogeny.

Other study of Alexandrou, Taylor (2011) corroborates these findings and also brings a discussion about the high variation in chromosome number among Corydoradinae species.

Considering the extreme variation in DNA content among Corydoradinae species and that this variation may be expressed in differences in the male reproductive system, mainly in the structure of spermatozoa, this study aims: 1analyze the anatomy and histology of the male reproductive system of representatives of the nine Corydoradinae lineages identified by Alexandrou et al. (2011); 2 - perform a morphometric analysis of the heads of spermatozoa of species belonging to each of the nine lineages, in order to test the hypothesis that the genomic variability of those lineages is related with the degree of chromatin condensation during the process of spermiogenesis, influencing the size of the head of gametes.

\section{Materials and methods}

This study was conducted with adult males from 31 species representing nine lineages of Corydoradinae. Most specimens were obtained in the fish collection of Laboratório de Biologia e Genética de Peixes (LBP), Departamento de Morfologia, Instituto de Biociências, UNESP, Botucatu, São Paulo, Brazil. Some species were captured by new collecting expeditions in different rivers of the Brazilian Hydrographic Basins, which were catalogued in the same collection. The taxa obtained were listed in the Appendix 1 (S1 - Available only as online supplementary files accessed with the online version of the article at http://www.scielo.br/ni).

The collected specimens were anesthetized with 1\% benzocaine solution before dissection. The male reproductive system was removed from all fishes.

For anatomical analyzes, the male reproductive system was removed under a stereomicroscope (Olympus - SZX7) and analyzed regarding the differentiated regions and genital papilla. Images of the structures were captured using an Olympus DP-25 digital camera coupled with stereomicroscope and microcomputer, with image capture software cellSens for Dimension, Olympus.

For histological studies, testes, seminal vesicles and genital papilla were fixed in 2\% glutaraldehyde and $4 \%$ paraformaldehyde in $0.1 \mathrm{M}$ Sorensen phosphate buffer, $\mathrm{pH}$ 7.4 for 24 hours. Then, the materials were dehydrated in alcohol and embedded in Leica Historesin - Embedding Kit. Sections from 3 to $5 \mu \mathrm{m}$ thick were stained with Hematoxylin and Eosin, Toluidine Blue and Periodic Acid Schiff (PAS) stain. Micrographs were obtained using an Olympus DP-25 digital camera coupled with microscope BX41 - Olympus and microcomputer using the DP2-BSW image capture software.

Appendix 2 (S2- Available only as online supplementary files accessed with the online version of the article at http:// www.scielo.br/ni) shows the type of morphologic analysis performed on the sampled species. Although samples from the nine lineages were obtained, it was not possible to perform all of the proposed analyzes on the nine lineages, due to immature testes and, therefore, not containing all cells from the spermatogenic lineage, mainly spermatozoa and/or batches with high number of females. Besides, the description of the histology of genital papilla for some species was not performed, due to the difficulty in obtaining histological sections of this extremely small structure; therefore most of the times only determining the anatomic characterization.

Morphometry of the spermatozoon head was performed with samples stained with toluidine blue. For each species of the analyzed lineages two histological slides of the testes were obtained, from which digital images of, at least, 10 histological fields were captured.

Based on the mean dispersion of head diameters, obtained in a preliminary measurements, it was calculated the minimum sample size necessary for characterize the assessed sperm population (Gallego et al., 2012). Thus, the minimum sample size was established between 50 and 70 measurements. Only 
in Corydoras duplicareus, from lineage 9, the number of measurements reached was 33 cells, because the testes had few spermatozoa.

Afterwards, the heads of spermatozoa of each species, located on the lumen of seminiferous tubules, were measured by means of software cellSens for Dimension, Olympus. The determined parameters were: diameter $(\mu \mathrm{m})$, area $\left(\mu \mathrm{m}^{2}\right)$ and perimeter $(\mu \mathrm{m})$ of the nuclei of spermatozoa. The morphometry of spermatozoa heads was performed in at least one species of each lineage, except on lineage 5, since the sampled species, Corydoras elegans, had spermatids only inside the seminiferous tubules.

Data obtained were compared by variance analysis one-way ANOVA, with Bonferroni's post-test. Differences were considered as statistically significant when $p<0.05$. Statistical analyzes were performed in program GraphPad Prism (version 6.0; GraphPad Software, Inc., La Jolla, CA, USA).

\section{Results}

Anatomy of the testes and accessory glands. On the analyzed species, regardless of the lineage, testes are paired elongated organs, fixed to the dorsal wall of the body by a mesorchium, a thin layer of peritoneum. Both testes join in the caudal extremity, converging in a central spermatic duct system, which extends to the external environment through the genital papilla (Figs. 1a-d).

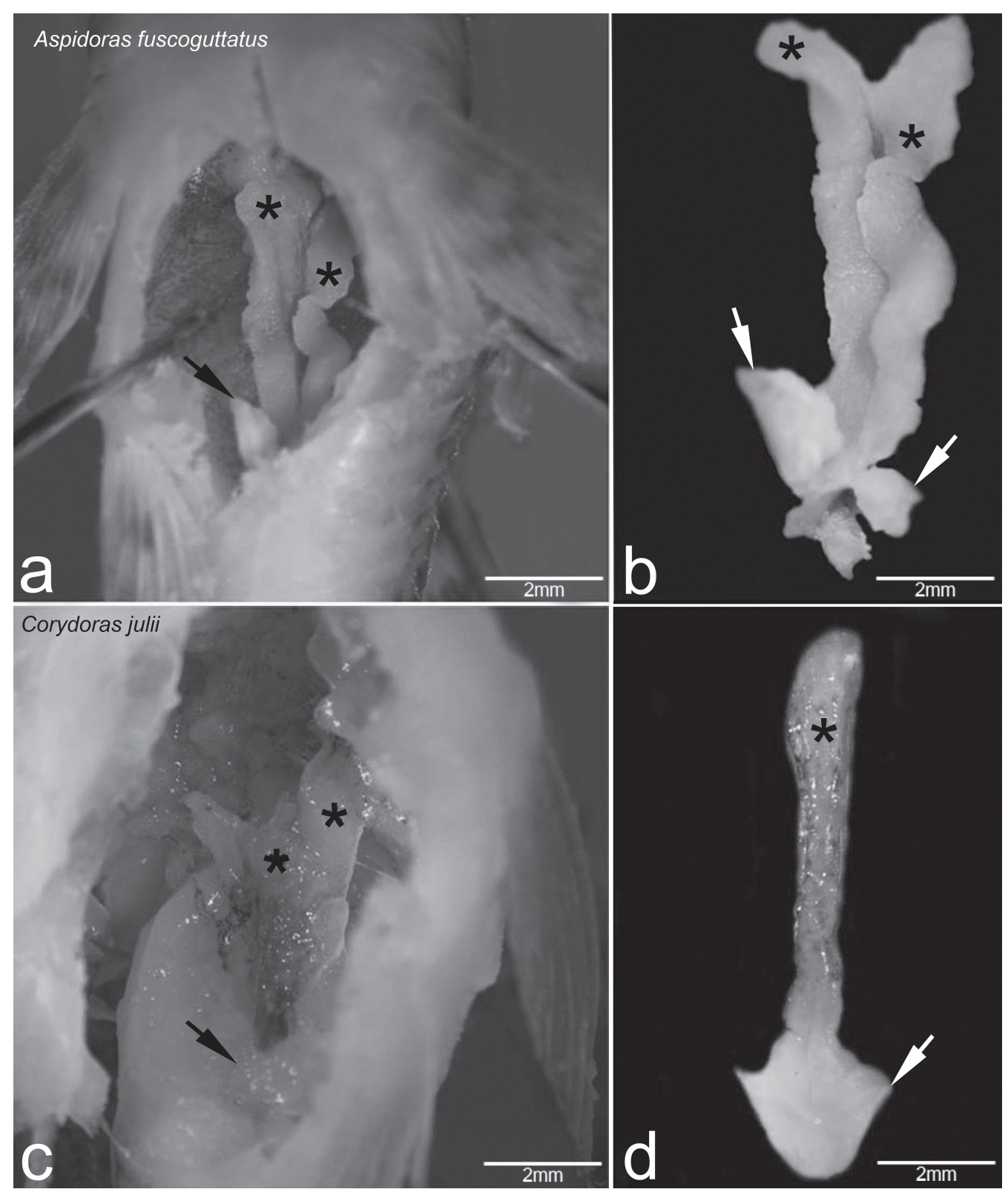

Fig. 1. Ventral view of adult males, evidencing the testes and the seminal vesicle. a, b. Aspidoras fuscoguttatus; c, d. Corydoras julii. Arrows point to the seminal vesicles in different positions, being lateral to the testes in A. fuscoguttatus and ventral in $C$. julii. Asterisk: testis. 
Presence of accessory glands in the male reproductive system was observed on the different lineages of Corydoradinae (Tab. 1). Based on Tab. 1, it is observed that at least one species of each lineage has seminal vesicle. Particularly, this structure is present in all analyzed species from lineages 2, 6 and 8. In other lineages, there are species without any evidence of the presence of seminal vesicles.

Macroscopically, the seminal vesicles have different colors from those observed on testes, more white and with the presence of small globules. These structures are paired, located at the ventral side of the testes and are a part of the efferent ducts, in most of the species analyzed. Differently, on the species of lineage 2, Aspidoras poecilus and $A$. fuscoguttatus and on the ones of lineage 3, Scleromystax kronei and S. barbatus, the accessory glands are located laterally to the ventral side of the testes (Figs. 1b, d).

Tab. 1. Occurrence of seminal vesicle and its position relative to the testis by species analyzed according to lineage. Yes = presence, No $=$ absence.

\begin{tabular}{|c|c|c|c|}
\hline \multirow{2}{*}{ Lineages } & \multirow{2}{*}{ Species } & \multicolumn{2}{|c|}{ Seminal Vesicle } \\
\hline & & Occurrence & Position \\
\hline \multirow{6}{*}{1} & Corydoras maculifer & No & - \\
\hline & Corydoras serratus & No & - \\
\hline & Corydoras narcissus & No & - \\
\hline & Corydoras fowleri & Yes & Ventral \\
\hline & Corydoras sp. C53 'luminoso' & No & - \\
\hline & Corydoras aff. areio & No & - \\
\hline \multirow{5}{*}{2} & Aspidoras fuscoguttatus & Yes & Lateral \\
\hline & Aspidoras poecilus & Yes & Lateral \\
\hline & Aspidoras sp. LBP 15714 & Yes & Ventral \\
\hline & Aspidoras sp. LBP 15850 & Yes & Ventral \\
\hline & Aspidoras taurus & Yes & Ventral \\
\hline \multirow{4}{*}{3} & Scleromystax macropterus & No & - \\
\hline & Scleromystax kronei & Yes & Lateral \\
\hline & Scleromystax barbatus & Yes & Lateral \\
\hline & Scleromystax prionotos & No & - \\
\hline \multirow{2}{*}{4} & Corydoras hastatus & No & - \\
\hline & Corydoras guapore & Yes & Ventral \\
\hline 5 & Corydoras elegans & No & - \\
\hline \multirow{4}{*}{6} & Corydoras flaveolus & Yes & Ventral \\
\hline & Corydoras nattereri & Yes & Ventral \\
\hline & Corydoras ehrhardti & Yes & Ventral \\
\hline & Corydoras sp. & Yes & Ventral \\
\hline 7 & Corydoras aeneus & Yes & Ventral \\
\hline \multirow{2}{*}{8} & Corydoras latus & Yes & Ventral \\
\hline & Corydoras seussi & Yes & Ventral \\
\hline \multirow{6}{*}{9} & Corydoras duplicareus & No & - \\
\hline & Corydoras julii & Yes & Ventral \\
\hline & Corydoras melini & Yes & Ventral \\
\hline & Corydoras araguaiaensis & Yes & Ventral \\
\hline & Corydoras cf. polystictus & Yes & Ventral \\
\hline & Corydoras cf. arcuatus & Yes & Ventral \\
\hline
\end{tabular}

Anatomy and histology of the genital papilla. It was observed that most of the species have genital papilla, except Corydoras elegans, from lineage 5 and C. araguaiaensis, from lineage 9 (Tab. 2). The genital papilla shows to be variable, mostly being elongated and with a tubular shape (Figs. 2-9, Tab. 2). Some variations were observed on genital papillae of Corydoras sp. C53 'luminoso', from lineage 1 and C. guapore, from lineage 4, whose extremity is forked and on Scleromystax macropterus, of lineage 3, which has oval shape (tumid) (Figs. 2, 4, 5). In males of Corydoras aff. areio, from lineage 1, of all species from lineage 2, of S. kronei and S. barbatus, from lineage 3, of C. flaveolus, from lineage 6 and C. aeneus, from lineage 7 , the genital papilla is lanceolate shaped (Figs. 2, 3, 4, 6, 7)

Histologically, the genital papillae of males from the studied species, independently of lineage, are constituted by dense connective tissue, smooth muscle cells, and blood vessels. The papilla epithelium is stratified squamous, with some mucous cells between the epithelial cells. Papillae have a central lumen lined by a simple columnar epithelium. Inside the lumen, a positive PAS secretion is observed (Figs. 2-9).

Tab. 2. List of species analyzed by genetic lineage, showing the occurrence of genital papilla in males and its shape. Yes $=$ presence, No $=$ absence.

\begin{tabular}{|c|c|c|c|}
\hline \multirow{2}{*}{ Lineages } & \multirow{2}{*}{ Species } & \multicolumn{2}{|c|}{ Genital Papilla } \\
\hline & & Occurrence & Shape \\
\hline \multirow{6}{*}{1} & Corydoras maculifer & Yes & Tubular \\
\hline & Corydoras serratus & Yes & Tubular \\
\hline & Corydoras narcissus & Yes & Tubular \\
\hline & Corydoras fowleri & Yes & Tubular \\
\hline & Corydoras sp. C53'luminoso' & Yes & Tubular (forked) \\
\hline & Corydoras aff. areio & Yes & Lance \\
\hline \multirow{5}{*}{2} & Aspidoras fuscoguttatus & Yes & Lance \\
\hline & Aspidoras poecilus & Yes & Lance \\
\hline & Aspidoras sp. LBP 15714 & Yes & Lance \\
\hline & Aspidoras sp. LBP 15850 & Yes & Lance \\
\hline & Aspidoras taurus & Yes & Lance \\
\hline \multirow{4}{*}{3} & Scleromystax macropterus & Yes & Tubular (oval) \\
\hline & Scleromystax kronei & Yes & Lance \\
\hline & Scleromystax barbatus & Yes & Lance \\
\hline & Scleromystax prionotos & Yes & Tubular \\
\hline \multirow{2}{*}{4} & Corydoras hastatus & Yes & Tubular \\
\hline & Corydoras guapore & Yes & Tubular (forked) \\
\hline 5 & Corydoras elegans & No & - \\
\hline \multirow{4}{*}{6} & Corydoras flaveolus & Yes & Lance \\
\hline & Corydoras nattereri & Yes & Tubular \\
\hline & Corydoras ehrhardti & Yes & Tubular \\
\hline & Corydoras sp. & Yes & Tubular \\
\hline 7 & Corydoras aeneus & Yes & Lance \\
\hline \multirow{2}{*}{8} & Corydoras latus & Yes & Tubular \\
\hline & Corydoras seussi & Yes & Tubular \\
\hline \multirow{5}{*}{9} & Corydoras duplicareus & Yes & Tubular \\
\hline & Corydoras julii & Yes & Tubular \\
\hline & Corydoras melini & Yes & Tubular \\
\hline & Corydoras araguaiaensis & No & - \\
\hline & Corydoras cf. polystictus & Yes & Tubular \\
\hline
\end{tabular}



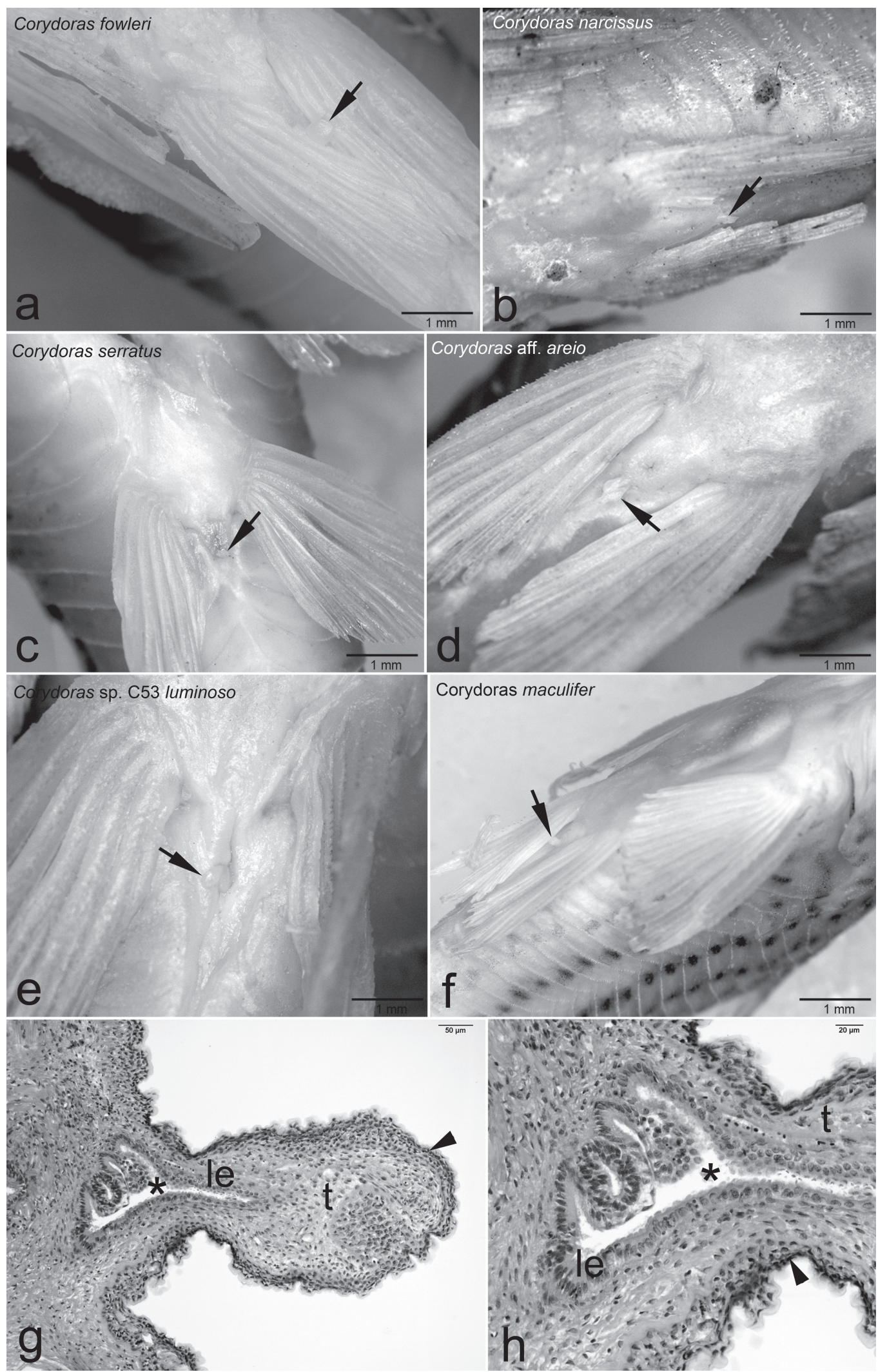

Fig. 2. Ventral view of adult males from Lineage 1, showing the genital papila. a. Corydoras fowleri; b. C. narcisus; c. C. serratus; d. Corydoras aff. areio; e. Corydoras sp. C53 luminoso; f. Corydoras maculifer. Arrows point to the genital papilla, evidencing elongated tubular shape. $\mathbf{g}$, h. Longitudinal sections of the genital papilla in C. maculifer, showing the histology of the organ. le: lumen epithelium; t: connective tissue; arrow head: epithelium of the papilla; asterisk: lumen. Staining: Hematoxylin and Eosin. 

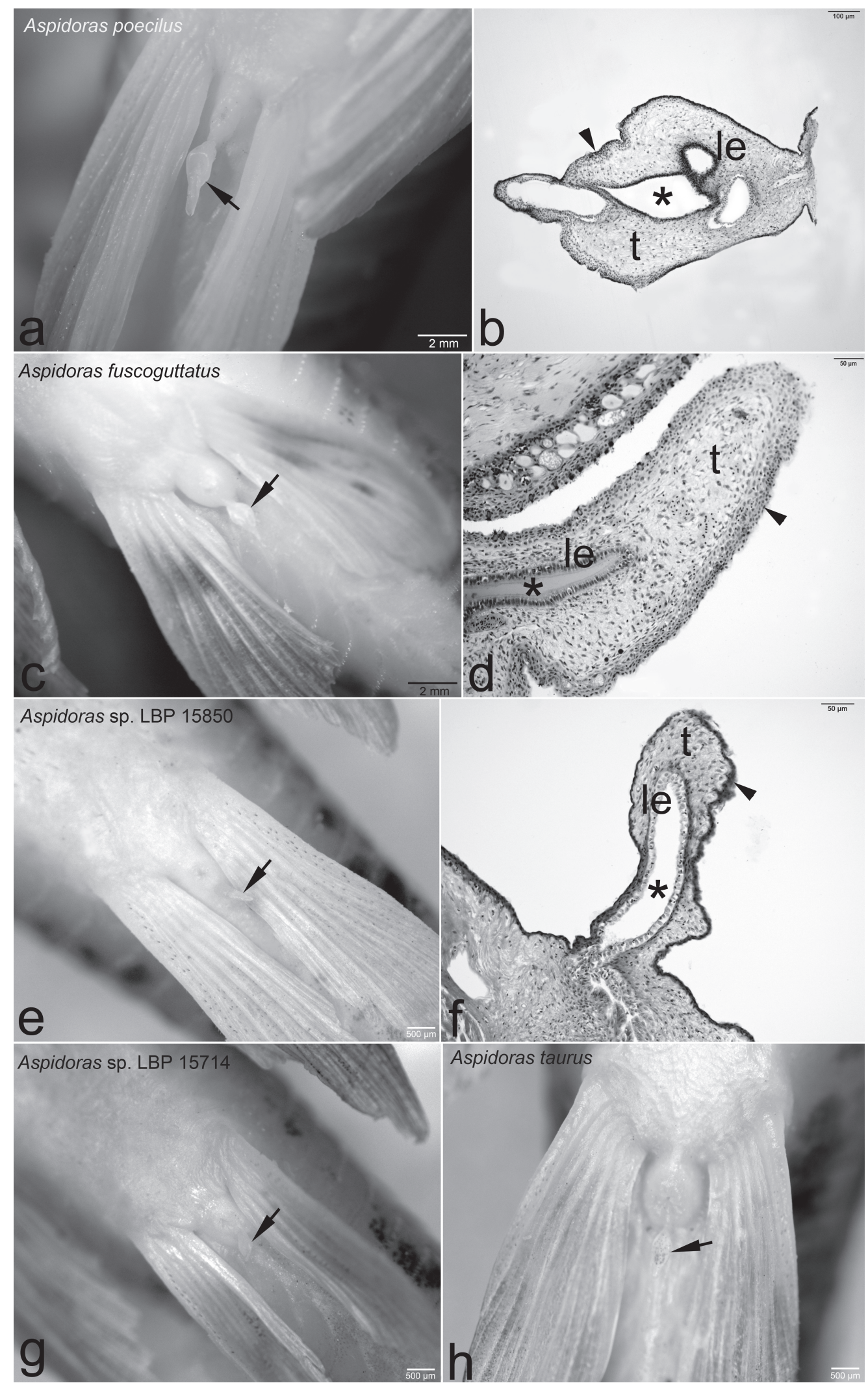

Fig. 3. Ventral view of adult males from Lineage 2, showing the genital papilla. a. Aspidoras poecillus; c. A. fuscoguttatus; e. Aspidoras sp. LBP 15850; g. Aspidoras sp. LBP 15714; h. A. taurus. Arrows point to the genital papilla, evidencing lanceolate shape. Longitudinal sections of the genital papilla, exhibiting the histology of the organ. b. A. poecilus, d. A. fuscoguttatus; f. Aspidoras sp. LBP 15850. le: lumen epithelium; t: connective tissue; arrow head: epithelium of the papilla; asterisk: lumen. Staining: b. Toluidine Blue; d. Periodic acid Schiff; f. Hematoxylin and Eosin. 

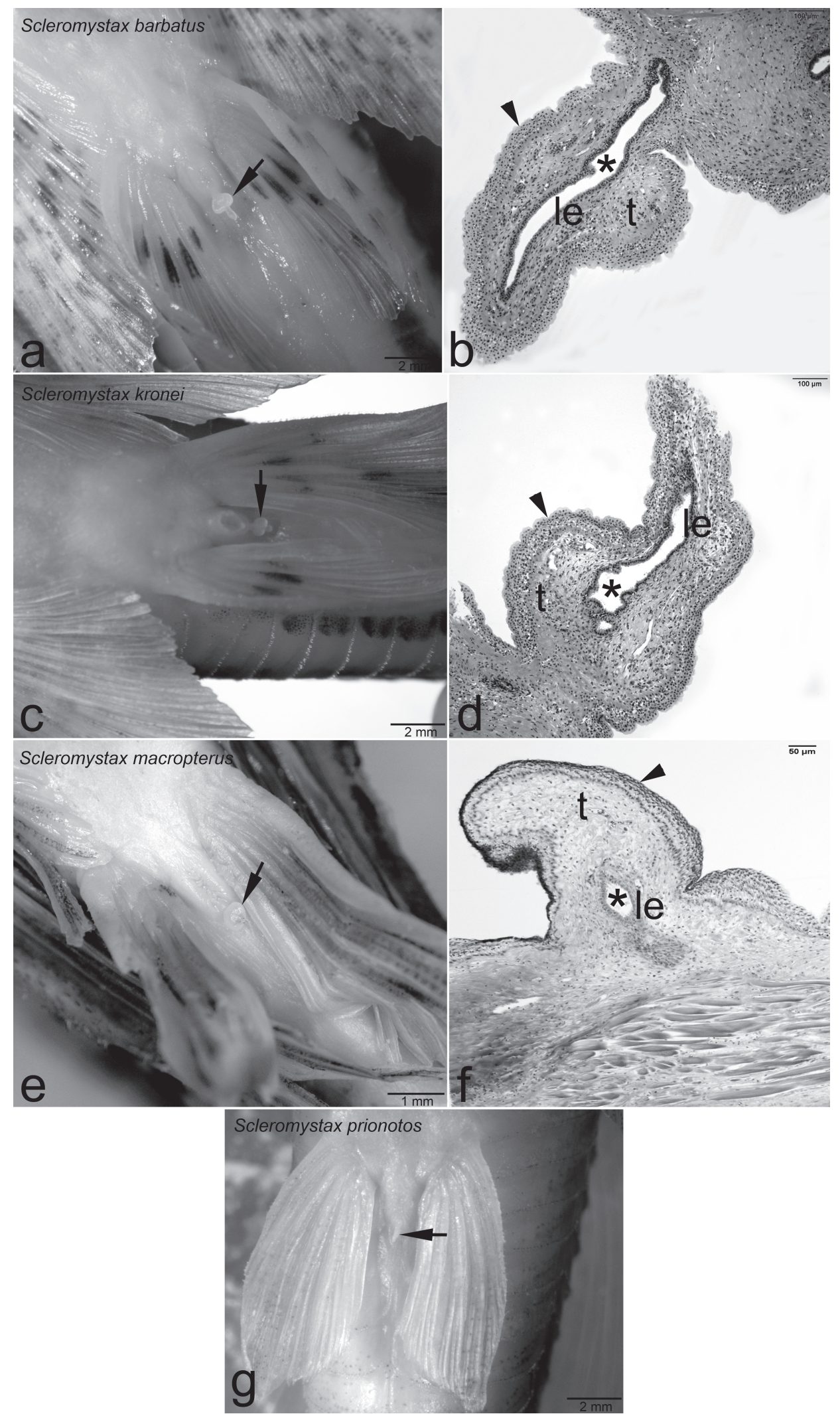

Fig. 4. Ventral view of adult males from Lineage 3, showing the genital papilla. a. Scleromystax barbatus; c. S. kronei; e. S. macropterus; g. Scleromystax prionotos. Arrows point to the genital papilla, evidencing lanceolate shape in S. barbatus and $S$. kronei, and tubular shape in S. macropterus and S. prionotos. Longitudinal sections of the genital papilla, exhibiting the histology of the organ. b. S. barbatus; d. S. kronei; f. S. macropterus. le: lumen epithelium; t: connective tissue; arrow head: epithelium of the papilla; asterisk: lumen. Staining: Hematoxylin and Eosin. 


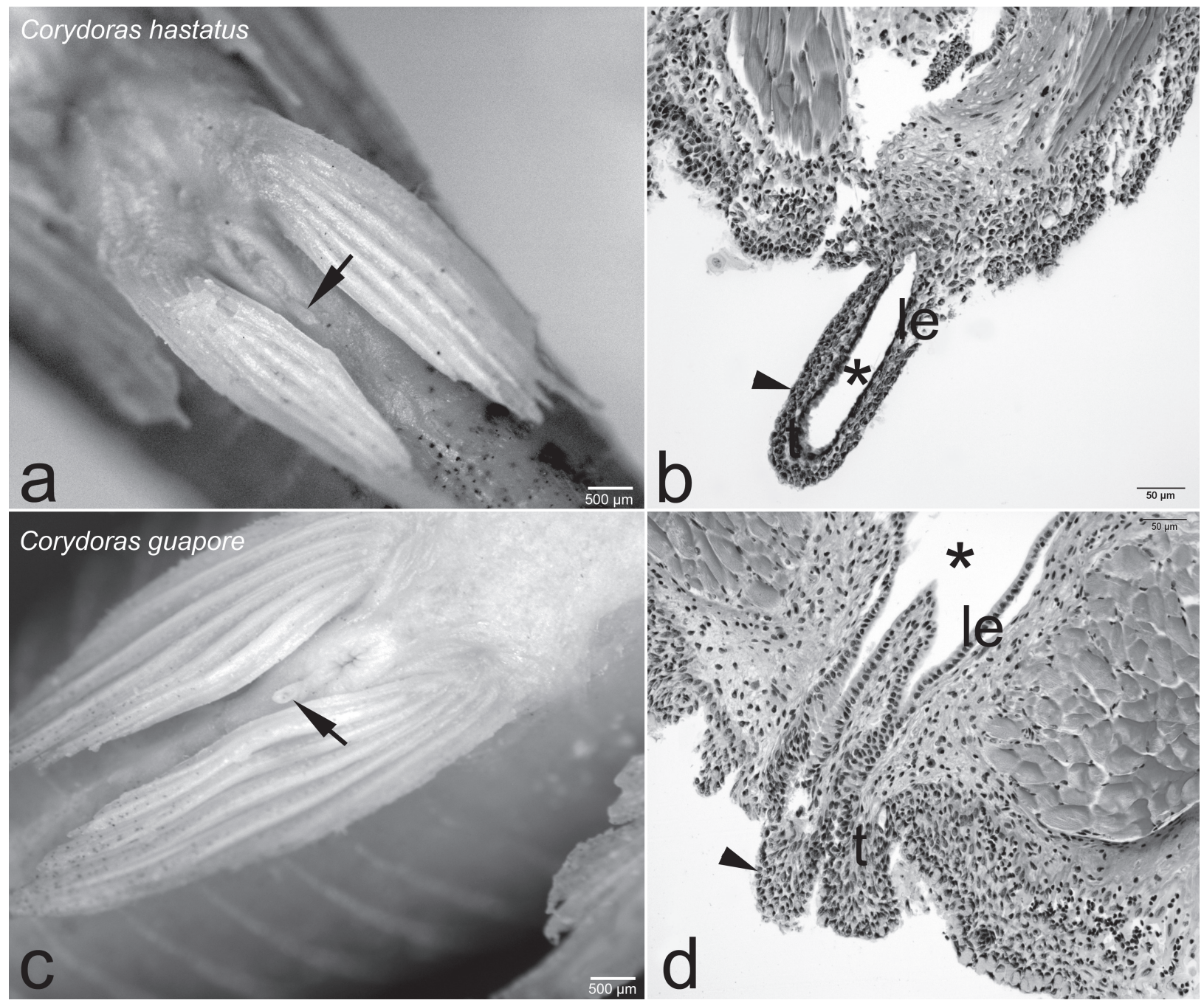

Fig. 5. Ventral view of adult males from Lineage 4, showing the genital papilla. a. Corydoras hastatus; c. C. guapore. Arrows point to the genital papilla, evidencing tubular shape. Longitudinal sections of the genital papilla, exhibiting the histology of the organ. b. C. hastatus; d. C. guapore. le: lumen epithelium; t: connective tissue; arrow head: epithelium of the papilla; asterisk: lumen. Staining: b. Toluidine Blue; d. Hematoxylin and Eosin.

Histology of testes. The testicular histological pattern observed on species of all studied lineages has great similarity (Figs. 10-19). The analyzed testes are surrounded by a capsule of connective tissue (tunica albuginea) and have, internally, seminiferous tubules covered by the germinal epithelium, having cysts with germ cells in differentiation. The typical testicular structure with the division on germinal and interstitial compartments was observed (Figs. 10a-h, 11a-d, 12a, d, e, g, 13a, c, d, f, 14a-c, 15a, b, 16a, e, f, h, 17a, d, 18a, c, 19a, b, d, e-g).

In the analyzed Corydoradinae from different lineages, the observed testicular organization is of the anastomosing tubular type, with seminiferous tubules suffering anastomoses at different heights of the organ, mainly in the region of the spermatic duct. Also regarding the germinal compartment, primary spermatogonia surrounded by Sertoli cell processes are observed. These cells proliferate mitotically, giving rise to an isogenic clone of secondary spermatogonia enclosed within a cysts or spermatocysts. After, the secondary spermatogonia enter into meiosis and, becoming the primary spermatocytes. When the first division of meiosis is completed, secondary spermatocytes are formed and, after these cells giving rise to spermatids.

Regarding spermatids, it was observed in all analyzed species of Corydoradinae, independently of the allocated lineage, that these cells are in the lumen of the seminiferous tubules and, therefore, not delimited inside cysts. At the end of meiosis, cysts open, early spermatids are released into the lumen, forming cell clusters. In the lumen, these cells continue their development until to form the spermatozoa. The differentiation process of spermatids (spermiogenesis) is asynchronous and, therefore, various levels of differentiation of germ cells are observed, leading to the mixture of different cell types with newly formed spermatozoa into the lumen (Figs. 10a-h, 11a-d, 12a, d, e, g, 13a, c, d, f, 14a-c,15a, b, 16a, e, f, h, 17a, d, 18a, c, 19a, b, d, e-g). 

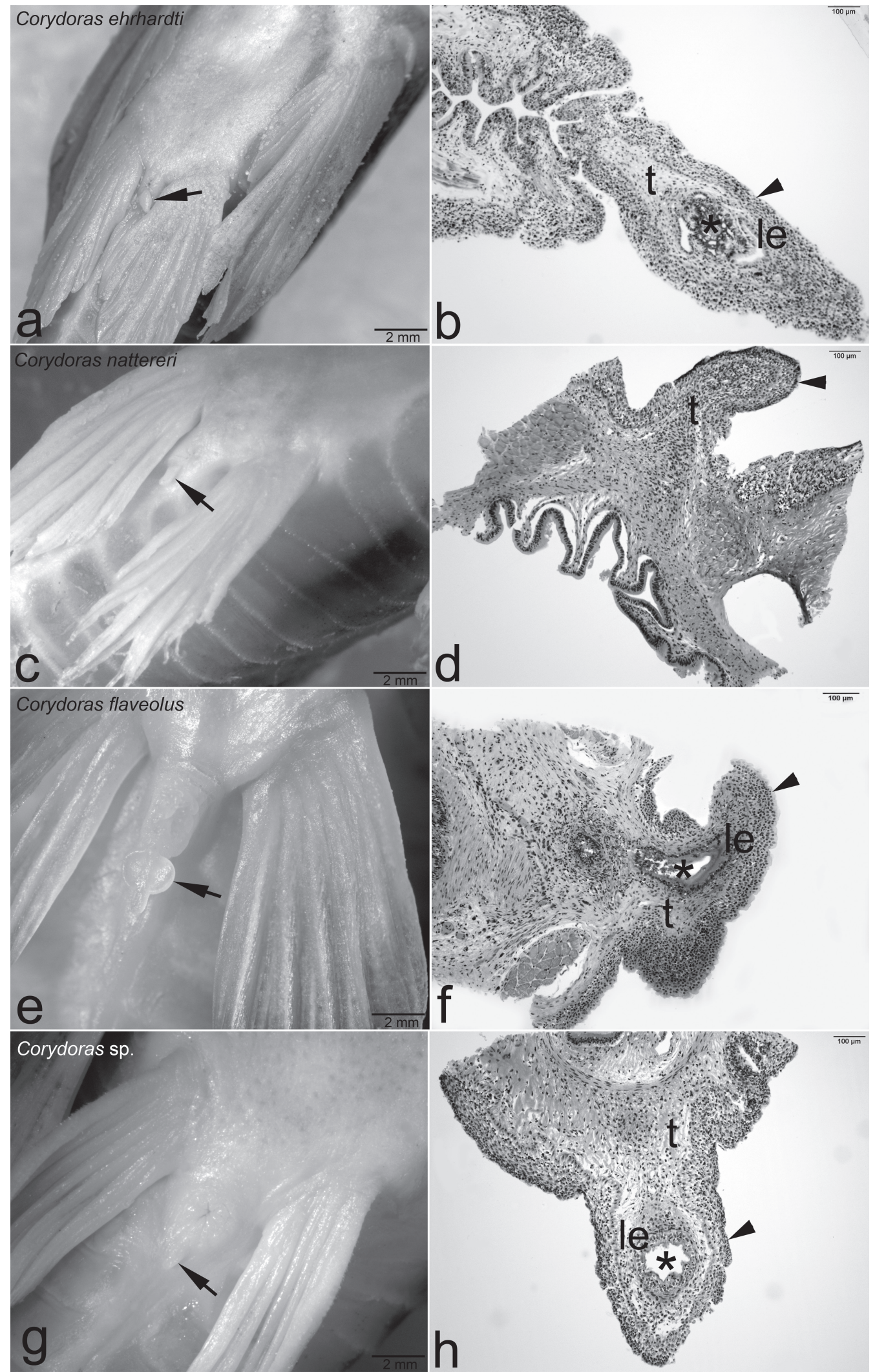

Fig. 6. Ventral view of adult males from Lineage 6, showing the genital papilla. a. Corydoras ehrhardti; c. C. nattereri; e. C. flaveolus; g. Corydoras sp. Arrows point to the genital papilla, evidencing lanceolate shape in C. flaveolus and elongated tubular shape in C. ehrhardti, C. nattereri and Corydoras sp. Longitudinal sections of the genital papilla, exhibiting the histology of the organ. b. C. ehrhardti; d. C. nattereri; f. C. Alaveolus; h. Corydoras sp. le: lumen epithelium; t: connective tissue; arrow head: epithelium of the papilla; asterisk: lumen. Staining: b, f. Toluidine Blue; d, h. Hematoxylin and Eosin. 

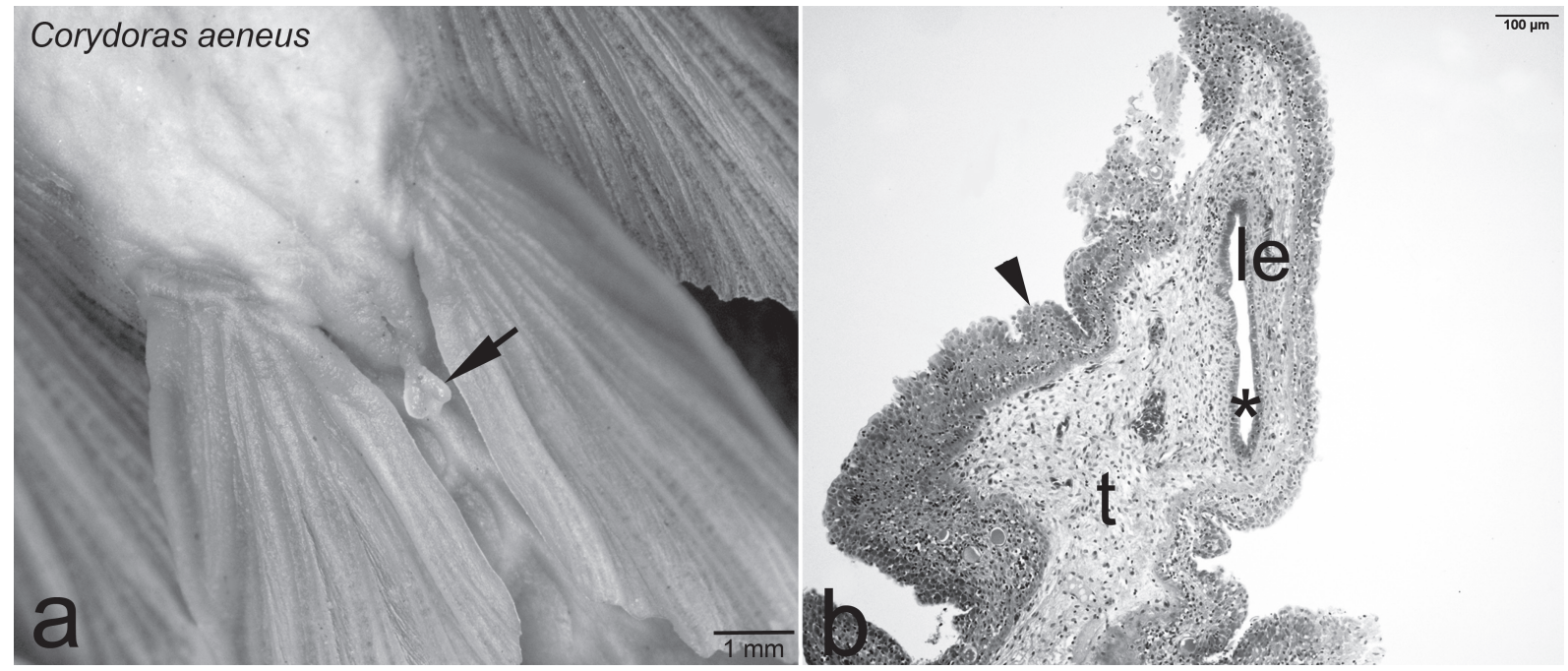

Fig. 7. Ventral view of adult male of C. aeneus from Lineage 7, showing the genital papilla. a. Arrow points to genital papilla, evidencing lanceolate shape. b. Longitudinal sections of the genital papilla, exhibiting the histology of the organ. le: lumen epithelium; t: connective tissue; arrow head: epithelium of the papilla; asterisk: lumen. Staining: Hematoxylin and Eosin.

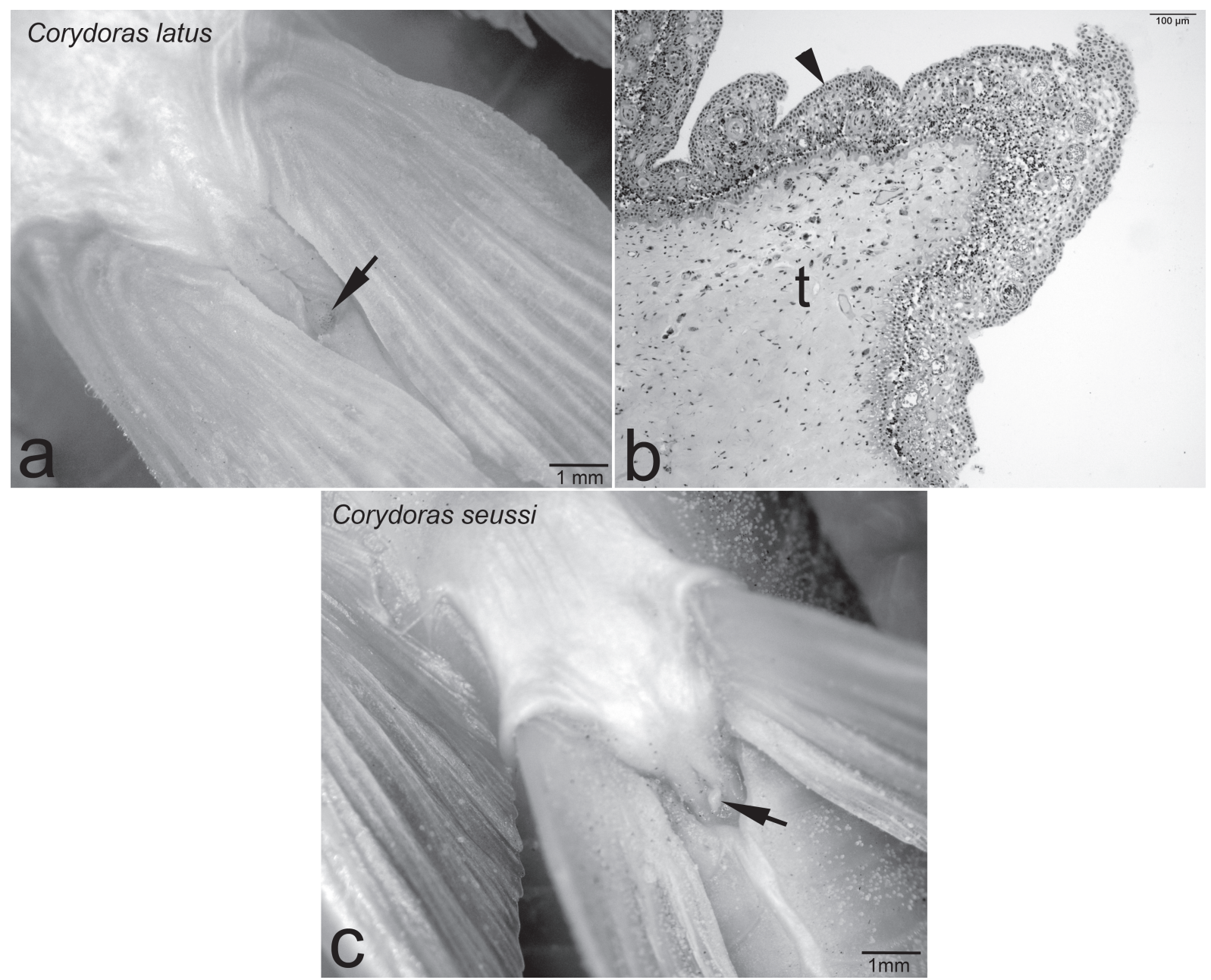

Fig. 8. Ventral view of adult males from Lineage 8, showing the genital papilla. a. Corydoras latus; c. C. seussi. Arrows point to the genital papilla, evidencing tubular shape. b. Longitudinal sections of the genital papilla in C. latus, exhibiting the histology of the organ. t: connective tissue; arrow head: epithelium of the papilla. Staining: Toluidine Blue. 


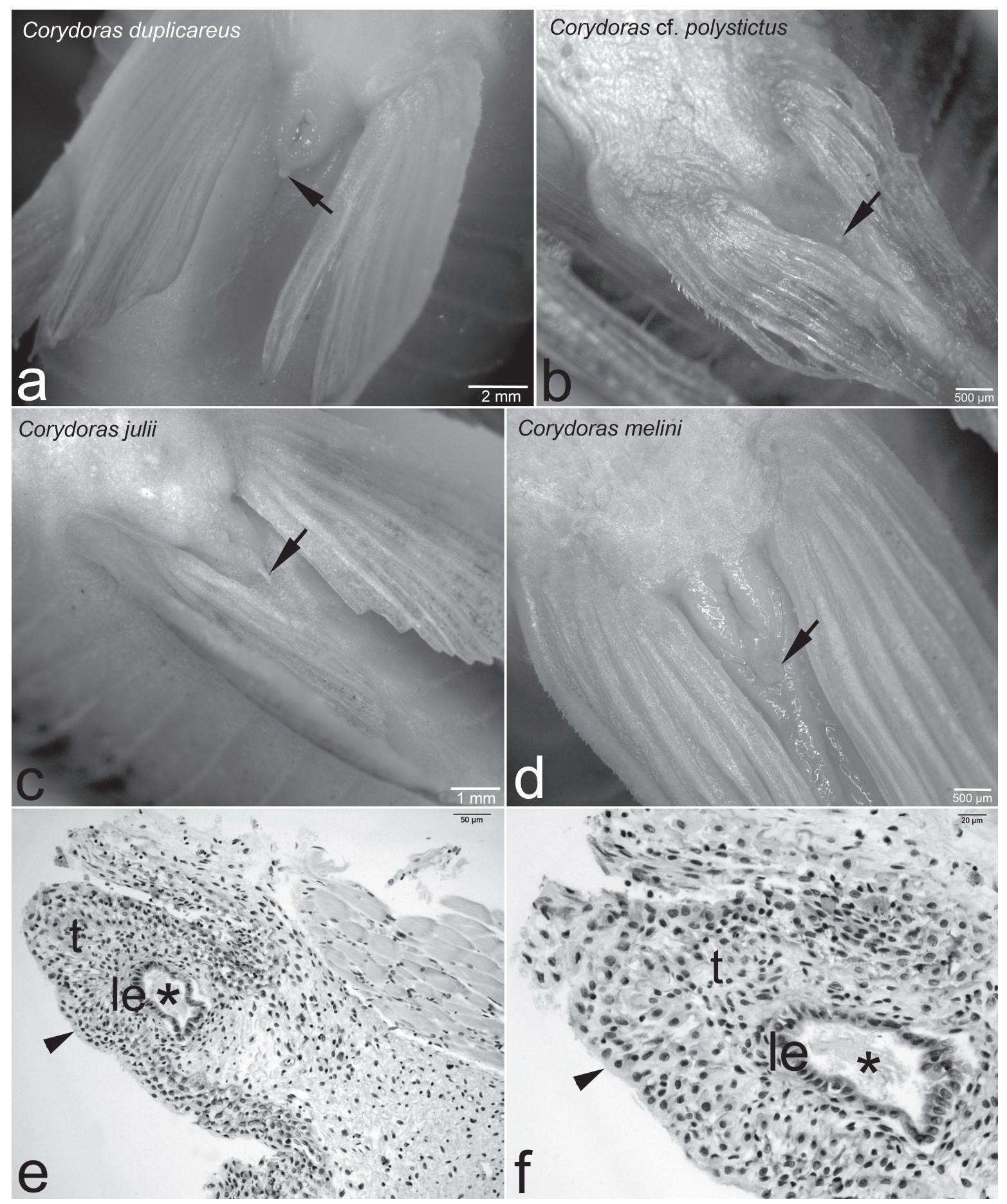

Fig. 9. Ventral view of adult males from Lineage 9, showing the genital papilla. a. Corydoras duplicareus; b. C. cf. polystictus; c. C. julii; d. C. melini. Arrows point to the genital papilla, evidencing tubular shape. e, f. Longitudinal sections of the genital papilla in C. melini, exhibiting the histology of the organ. le: lumen epithelium; t: connective tissue; arrow head: epithelium of the papilla; asterisk: lumen. Staining: Toluidine Blue.

Histology of accessory glands. The histological characteristics of the seminal vesicle of the analyzed species that have this structure reveal that they are composed by interconnected tubules, whose epithelium releases acidophilic secretion inside the spermatic ducts, which reacts positively to Periodic Acid Schiff staining, indicating the presence of glycoproteins. The epithelium, which covers the secretory tubules ranges from simple cubic to simple squamous. On the lumen of spermatic ducts present on the caudal region of testes are observed spermatozoa associated with the secretion (Figs. 12b, c, f, g, 13b, 16b, c, 17b, c, 18b, $\mathrm{d}, 19 \mathrm{c}, \mathrm{h})$. 


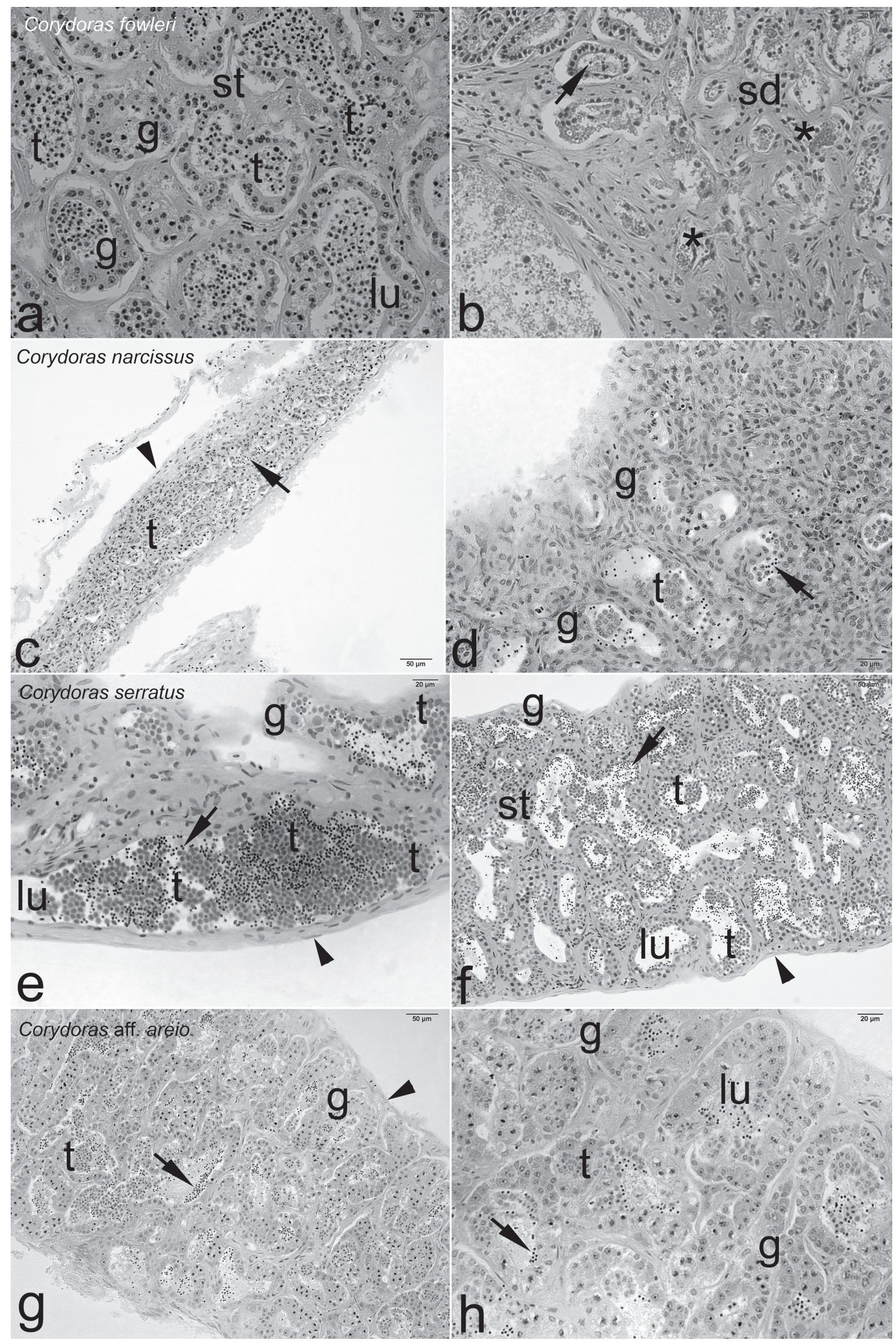

Fig. 10. Photomicrographs of the male reproductive system in species from Lineage 1, showing anastomosing seminiferous tubules (st), covered by germinal epithelium containing cysts with germinal cells. a, b. Corydoras fowleri; c, d. C. narcissus; e, f. C. serratus; g, h. C. aff. areio. Presence also of clusters of spermatids (t) on the lumen (lu). g: spermatogonia, sd: spermatic ducts, asterisk: acidophilic secretion, arrow: spermatozoa; arrow head: tunica albuginea. Staining: Hematoxylin and Eosin. 


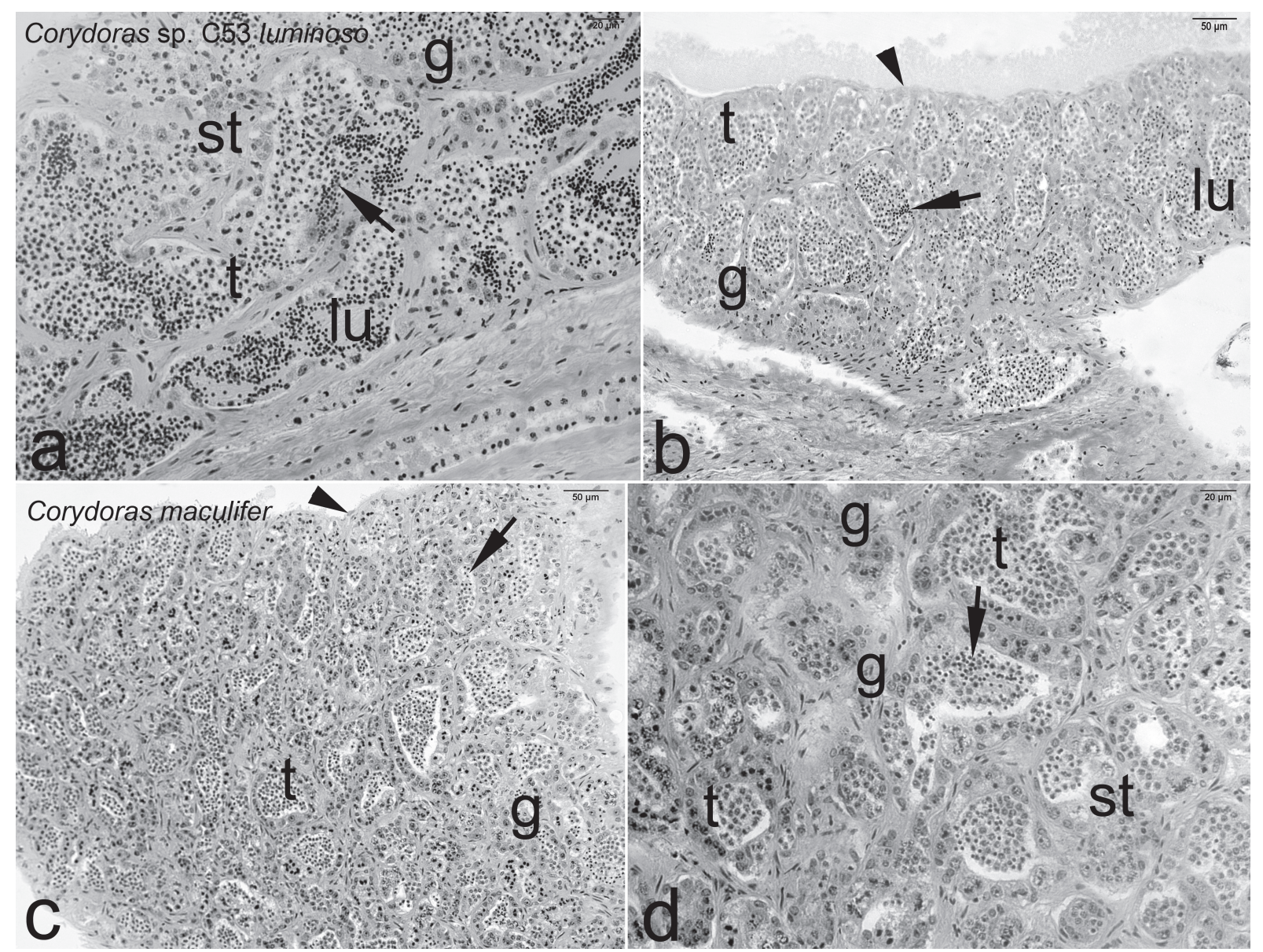

Fig. 11. Photomicrographs of the male reproductive system in other species from Lineage 1, showing anastomosing seminiferous tubules (st), covered by germinal epithelium containing cysts with germinal cells. a, b. Corydoras sp. C53 luminoso; c, d. C. maculifer. Presence also of clusters of spermatids (t) on the lumen (lu). g: spermatogonia, asterisk: acidophilic secretion; arrow: spermatozoa; arrow head: tunica albuginea. Staining: Hematoxylin and Eosin.

\begin{abstract}
Morphometric Analysis. Size of the heads of spermatozoa by lineage. Data obtained from measurements reveal that the size of the heads of spermatozoa from all analyzed species is variable inside and among the Corydoradinae lineages. By analyzing the means of diameter, area and perimeter it was possible to observe that lineages 1,2 and 3 are the ones with smaller sizes of heads of spermatozoa, while on species from lineages 4 and 6 to 9 , they are larger. The diameter of the heads of spermatozoa varied between 1.7 until $2.9 \mu \mathrm{m}$, the area covered from 2.4 until $7.8 \mu \mathrm{m}^{2}$ and the perimeter from 5.7 until 9.9 $\mu \mathrm{m}$ (Tab. 3). Size of the heads of spermatozoa by species of each lineage. Analysis of diameter, area and perimeter averages of the heads of spermatozoa from each analyzed species according to lineage also shows a trend to be smaller on species from lineages 1,2 and 3 , while the mean of species from the other lineages is larger (Tab. 4). When comparing date of DNA content with the size of the heads of spermatozoa from different species displayed on Tab. 4, it is possible to verify correlation between smaller DNA contents, associating with heads of size $<2.0 \mu \mathrm{m}$ regarding the diameter, for
\end{abstract}

example, this being verified on lineages from 1 to 3 . Diameters of heads of spermatozoa $\geq 2.0 \mu \mathrm{m}$ are related with species with greater DNA content, part of lineages 4 and from 6 to 9 .

Tab. 3. Averages of the heads of the spermatozoa from all species representatives of the genetic lineages of Corydoradinae. Values are Mean $\pm \mathrm{SD}, \mathrm{n}=$ measures number, $\mu \mathrm{m}=$ micrometer, $-\mathbf{~}=$ data not determined.

\begin{tabular}{cccccc}
\hline \multirow{2}{*}{ Lineages } & $\begin{array}{c}\text { Species } \\
\text { analyzed }\end{array}$ & $\mathrm{n}$ & \begin{tabular}{c} 
Diameter \\
\cline { 4 - 6 }$(\mu \mathrm{m})$
\end{tabular} & Area $\left(\mu \mathrm{m}^{2}\right)$ & $\begin{array}{c}\text { Perimeter } \\
(\mu \mathrm{m})\end{array}$ \\
\hline 1 & 6 & 864 & $1.7 \pm 0.1$ & $2.4 \pm 0.5$ & $5.7 \pm 0.5$ \\
2 & 4 & 629 & $1.7 \pm 0.2$ & $2.6 \pm 0.7$ & $5.8 \pm 0.8$ \\
3 & 3 & 446 & $1.8 \pm 0.2$ & $2.6 \pm 0.7$ & $5.8 \pm 0.7$ \\
4 & 1 & 118 & $2.5 \pm 0.1$ & $5.1 \pm 0.5$ & $8.3 \pm 0.4$ \\
5 & none & - & - & - & - \\
6 & 4 & 480 & $2.9 \pm 0.5$ & $6.9 \pm 2.3$ & $9.6 \pm 1.5$ \\
7 & 1 & 115 & $2.0 \pm 0.1$ & $2.9 \pm 0.3$ & $6.2 \pm 0.3$ \\
8 & 3 & 230 & $2.3 \pm 0.3$ & $4.6 \pm 1.1$ & $7.8 \pm 1.0$ \\
9 & 4 & 329 & $2.9 \pm 0.8$ & $7.8 \pm 4.2$ & $9.9 \pm 2.8$ \\
\hline
\end{tabular}


Tab. 4. Averages of the heads of spermatozoa from each analyzed species according to genetic lineage. Values are Mean $\pm \mathrm{SD}$, $\mathrm{n}=$ measures number, $\mathrm{pg}=$ picograms, $-=$ data not determined. *Alexandrou (2011), **Oliveira et al. (1993), ***Oliveira et al. (1992).

\begin{tabular}{|c|c|c|c|c|c|c|}
\hline \multirow{2}{*}{ Lineages } & \multirow{2}{*}{ Species } & \multicolumn{5}{|c|}{ Sperm head } \\
\hline & & Measures & Diameter $(\mu \mathrm{m})$ & Area $\left(\mu \mathrm{m}^{2}\right)$ & Perimeter $(\mu \mathrm{m})$ & n DNA (pg) \\
\hline \multirow{6}{*}{1} & Corydoras fowleri & 140 & $1.7 \pm 0.1$ & $2.5 \pm 0.2$ & $5.8 \pm 0.3$ & $0.65^{*}$ \\
\hline & Corydoras maculifer & 144 & $1.7 \pm 0.2$ & $2.5 \pm 0.8$ & $5.7 \pm 0.7$ & $0.65^{*}$ \\
\hline & Corydoras narcissus & 120 & $1.8 \pm 0.1$ & $2.6 \pm 0.3$ & $5.9 \pm 0.4$ & - \\
\hline & Corydoras serratus & 168 & $1.8 \pm 0.1$ & $2.6 \pm 0.3$ & $5.9 \pm 0.3$ & $0.7 *$ \\
\hline & Corydoras aff. areio & 110 & $1.6 \pm 0.1$ & $2.0 \pm 0.3$ & $5.2 \pm 0.4$ & - \\
\hline & Corydoras sp. C53'luminoso' & 185 & $1.6 \pm 0.1$ & $2.3 \pm 0.3$ & $5.4 \pm 0.4$ & $0.65^{*}$ \\
\hline \multirow{4}{*}{2} & Aspidoras fuscoguttatus & 210 & $1.8 \pm 0.2$ & $2.9 \pm 0.6$ & $6.1 \pm 0.7$ & $0.75 * *$ \\
\hline & Aspidoras poecilus & 118 & $1.9 \pm 0.2$ & $2.9 \pm 0.8$ & $6.2 \pm 0.8$ & $0.76^{*}$ \\
\hline & Aspidoras sp. LBP 15714 & 146 & $1.7 \pm 0.2$ & $2.3 \pm 0.5$ & $5.6 \pm 0.6$ & - \\
\hline & Aspidoras sp. LBP 15850 & 155 & $1.6 \pm 0.1$ & $2.1 \pm 0.4$ & $5.2 \pm 0.5$ & - \\
\hline \multirow{3}{*}{3} & Scleromystax barbatus & 190 & $1.8 \pm 0.3$ & $2.7 \pm 0.9$ & $5.9 \pm 0.9$ & $0.94 *$ \\
\hline & Scleromystax kronei & 150 & $1.8 \pm 0.1$ & $2.7 \pm 0.3$ & $6.0 \pm 0.3$ & $0.80^{*}$ \\
\hline & Scleromystax macropterus & 106 & $1.6 \pm 0.1$ & $2.2 \pm 0.3$ & $5.4 \pm 0.4$ & $0.82 *$ \\
\hline 4 & Corydoras hastatus & 118 & $2.5 \pm 0.1$ & $5.1 \pm 0.5$ & $8.3 \pm 0.4$ & $2.20^{*}$ \\
\hline 5 & Corydoras elegans & - & - & - & - & $2.24^{*}$ \\
\hline \multirow{4}{*}{6} & Corydoras ehrhardti & 130 & $2.6 \pm 0.2$ & $5.8 \pm 1.0$ & $8.8 \pm 0.8$ & $2.48^{*}$ \\
\hline & Corydoras flaveolus & 120 & $2.7 \pm 0.3$ & $5.5 \pm 0.8$ & $8.6 \pm 0.6$ & $2.46^{* * *}$ \\
\hline & Corydoras nattereri & 118 & $2.9 \pm 0.2$ & $6.4 \pm 0.8$ & $9.3 \pm 0.6$ & $1.79 * * *$ \\
\hline & Corydoras sp. & 112 & $3.6 \pm 0.3$ & $10.6 \pm 1.4$ & $11.9 \pm 0.8$ & - \\
\hline 7 & Corydoras aeneus & 115 & $2.0 \pm 0.1$ & $2.9 \pm 0.3$ & $6.2 \pm 0.3$ & $1.39^{* *}$ \\
\hline \multirow{2}{*}{8} & Corydoras seussi & 126 & $2.2 \pm 0.2$ & $4.1 \pm 0.9$ & $7.3 \pm 0.9$ & $2.16^{*}$ \\
\hline & Corydoras latus & 104 & $2.5 \pm 0.3$ & $5.2 \pm 0.1$ & $8.3 \pm 0.9$ & - \\
\hline \multirow{4}{*}{9} & Corydoras duplicareus & 33 & $3.4 \pm 0.3$ & $9.6 \pm 1.4$ & $11.4 \pm 0.8$ & $3.62 *$ \\
\hline & Corydoras julii & 73 & $2.6 \pm 0.2$ & $5.6 \pm 0.8$ & $8.6 \pm 0.7$ & $4.20 *$ \\
\hline & Corydoras melini & 101 & $2.1 \pm 0.1$ & $3.6 \pm 0.5$ & $6.8 \pm 0.5$ & $2.98 *$ \\
\hline & Corydoras cf. polystictus & 122 & $3.8 \pm 0.5$ & $12.0 \pm 3.1$ & $12.7 \pm 1.8$ & $3.42 *$ \\
\hline
\end{tabular}

Intra-lineage statistical analysis. Based on the statistical analysis of data obtained within each lineage it was verified that there are significant differences on the size of the heads of spermatozoa from species of the same lineage (Fig. 20).

On lineage 1 , the diameter and the perimeter of the head of spermatozoa of Corydoras aff. areio have no significant differences regarding Corydoras sp. C53 'luminoso' ( $>0.0001)$. When compared with the other species, $C$. fowleri, C. maculifer, C. narcissus and C. serratus, the size of the heads of spermatozoa of $C$. aff. areio has significant difference $(p<0.0001)$. There is no difference between heads of spermatozoa of Corydoras sp. C53 'luminoso' and $C$. fowleri, as well as between species C. maculifer, C. narcissus and C. serratus $(\mathrm{p}>0.0001)$. C. fowleri also has no difference in relation to $C$. maculifer, $C$. narcissus e C. serratus ( $\mathrm{p}>0.0001)$. Regarding the area of the heads of gametes, Corydoras aff. areio, Corydoras sp. C53 'luminoso' and C. fowleri have no significant difference, as well as between species Corydoras sp. C53 'luminoso', C. fowleri, C. maculifer, C. narcissus and C. serratus ( $>0.0001)$. Significant difference is only observed on the area of the heads of spermatozoa between Corydoras aff. areio and C. maculifer, C. narcissus and C. serratus species $(\mathrm{p}<0.0001)$ (Fig. 20a).

In lineage 2, data of diameter and perimeter have no significant differences for spermatozoa of $A$. fuscoguttatus and A. poecilus ( $\mathrm{p}>0.0001$ ), while between Aspidoras sp. LBP 15850 and Aspidoras sp. LBP 15714 a significant difference is observed $(\mathrm{p}<0.0001)$. Besides, the head of spermatozoa in Aspidoras sp. LBP 15850 and Aspidoras sp. LBP 15714 has significant difference regarding diameter and perimeter found in A. fuscoguttatus and A poecilus $(\mathrm{p}<0.0001)$. Regarding the area, the head of spermatozoa from Aspidoras sp. LBP 15850 and Aspidoras sp. LBP 15714 have no difference and the same occurs between $A$. fuscoguttatus and A. poecilus. There is significant difference between the area of the head of spermatozoa from Aspidoras sp. LBP 15850 and Aspidoras sp. LBP 15714 when compared with $A$. fuscoguttatus and A poecilus ( $<<0.0001)$ (Fig. 20b).

Regarding lineage 3 , there is no significant difference in diameter, area and perimeter of the heads of spermatozoa from $S$. kronei and $S$. barbatus ( $>0.0001)$, but between those and $S$. macropterus, a significant difference $(\mathrm{p}<0.0001)$ is observed (Fig. 20c). 

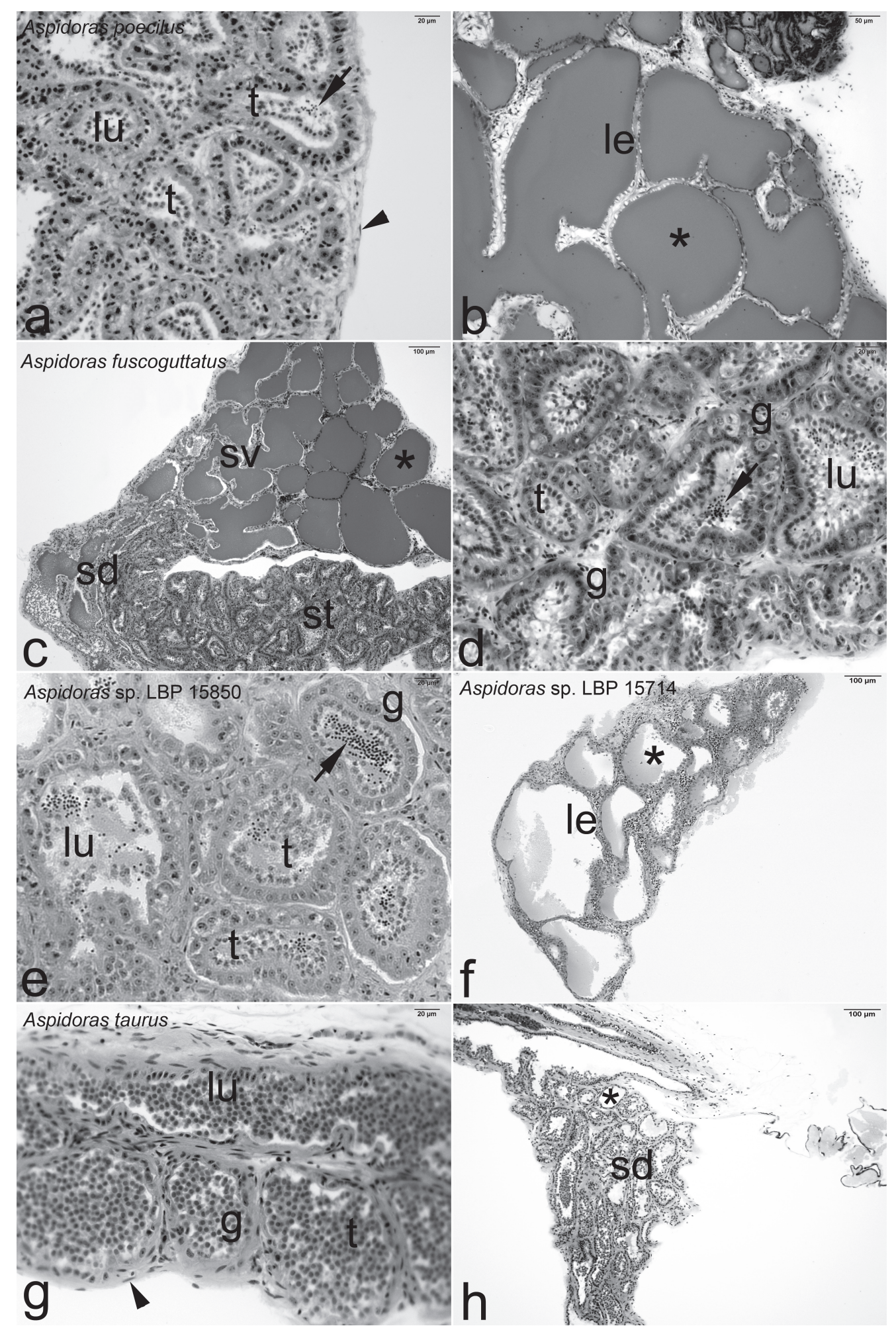

Fig. 12. Photomicrographs of the male reproductive system in species from Lineage 2, showing anastomosing seminiferous tubules (st), covered by germinal epithelium. a, b. Aspidoras poecillus; c, d. A. fuscoguttatus; e. Aspidoras sp. LBP 15850; f. Aspidoras sp. LBP 15714; g, h. A. taurus. Germinal epithelium containing cysts with germinal cells under development until meiosis. Presence on the tubular lumen (lu) of clusters of spermatids (t) mixed with recently formed spermatozoa, characterizing semicystic spermatogenesis. b, c, f. Secretory tubules of the seminal vesicle (sv) with lining epithelium (le), varying from simple cubic to simple squamous, releasing positive PAS secretion. $\mathbf{h}$. Region of spermatic ducts (sd). g: spermatogonia; asterisk: acidophilic secretion; arrow: spermatozoa; arrow head: tunica albuginea. Staining: a, e, f-h. Hematoxylin and Eosin; b. Toluidine Blue; c, d. Periodic Acid Schiff. 


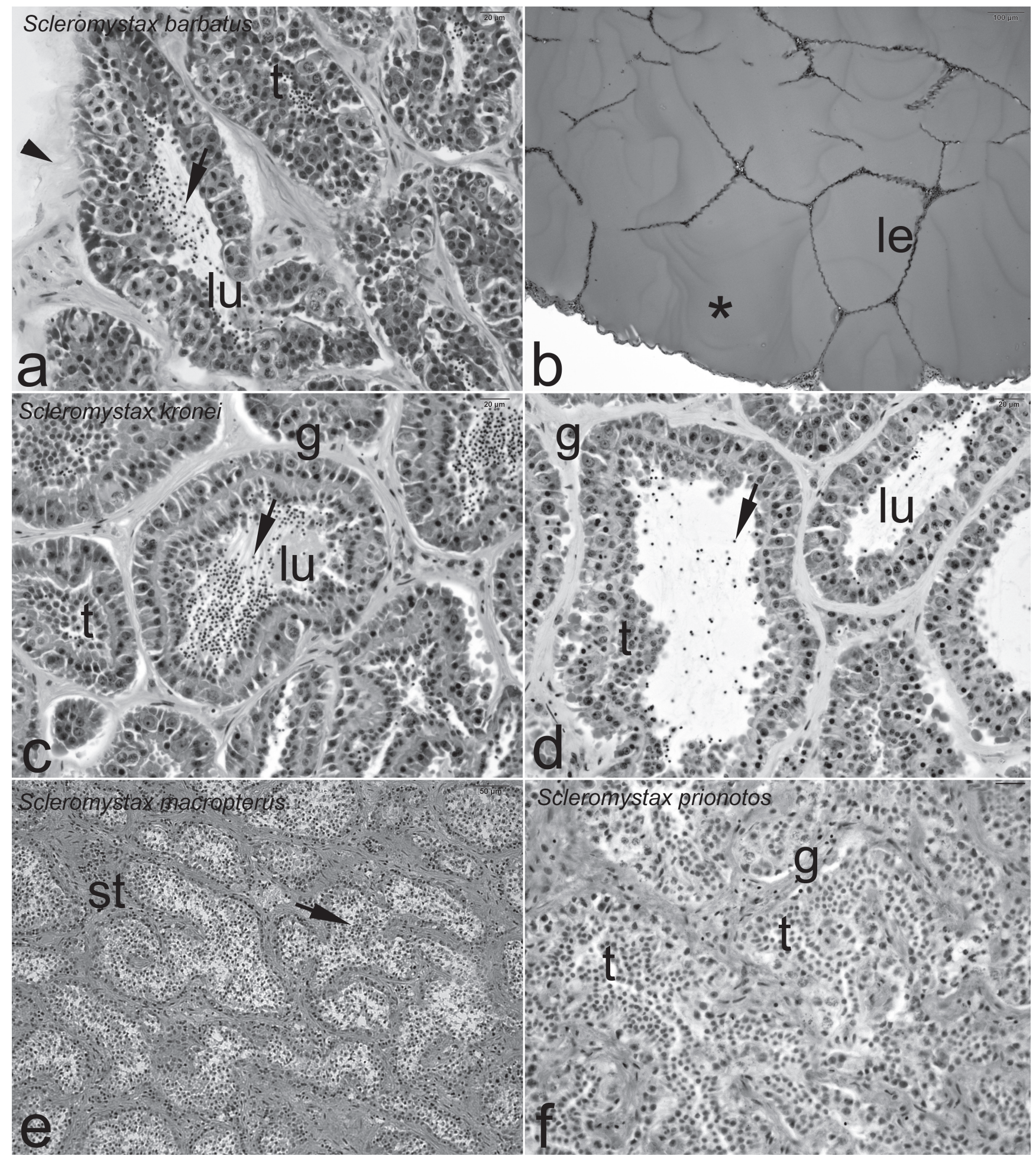

Fig. 13. Photomicrographs of the male reproductive system in species from Lineage 3, showing anastomosing seminiferous tubules (st), covered by germinal epithelium. a, b. Scleromystax barbatus; c, d. S. kronei; e. S. macropterus; f. $S$. prionotos. Germinal epithelium containing cysts with germinal cells under development until meiosis. Presence on the tubular lumen (lu) of clusters of spermatids ( $\mathrm{t}$ ) mixed with recently formed spermatozoa, characterizing semicystic spermatogenesis. b. Secretory tubules of the seminal vesicle with lining epithelium (le), varying from simple cubic to simple squamous, releasing positive PAS secretion. g: spermatogonia; asterisk: acidophilic secretion; arrow: spermatozoa; arrow head: tunica albuginea. Staining: a, b. Periodic Acid Schiff; c, e, f. Hematoxylin and Eosin; d. Toluidine Blue. 


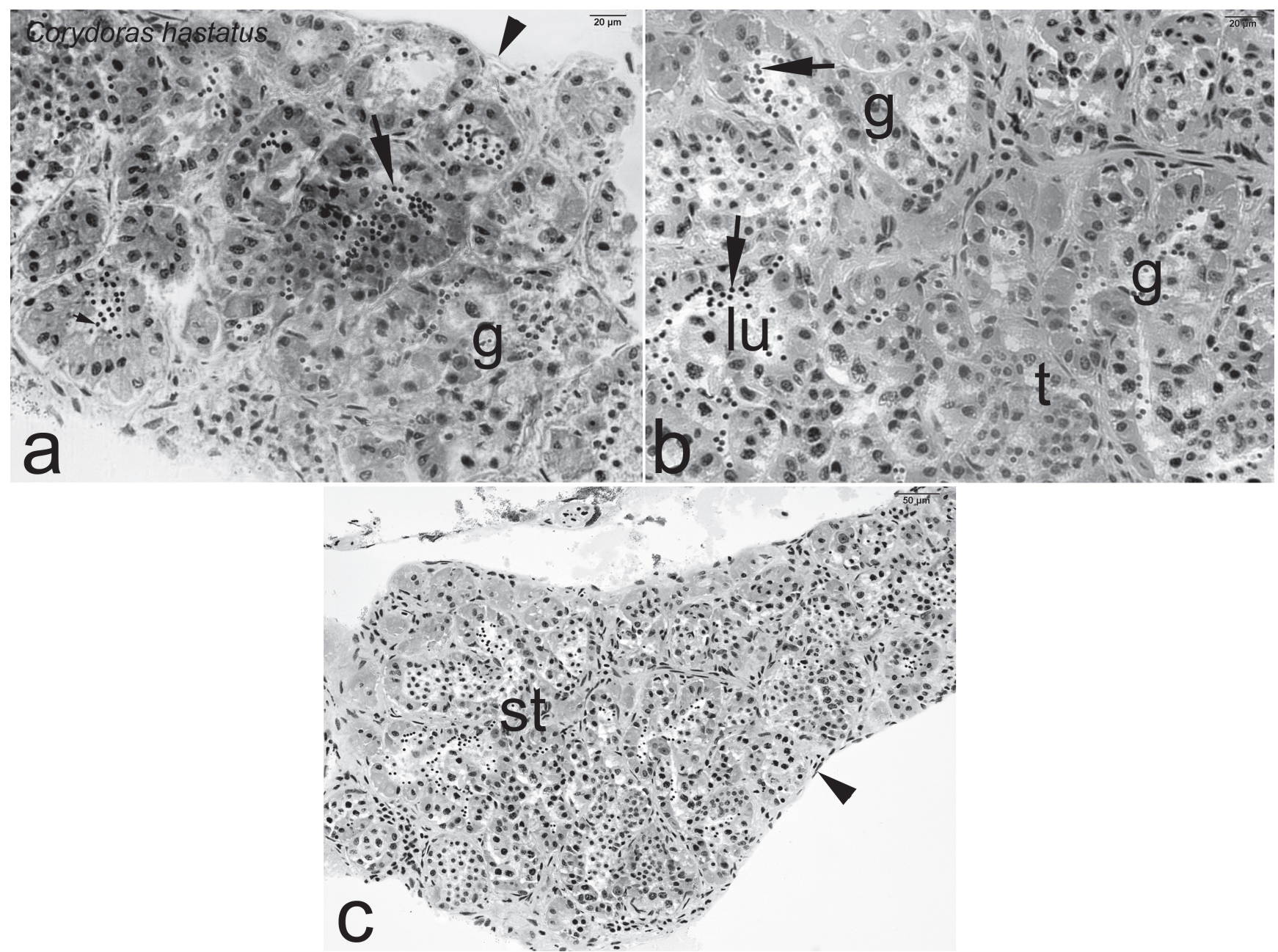

Fig. 14. Photomicrographs of the male reproductive system in C. hastatus from Lineage 4. a-c. Anastomosing seminiferous tubules (st), covered by germinal epithelium. Germinal epithelium containing cysts with germinal cells under development until meiosis. Presence on the tubular lumen (lu) of clusters of spermatids (t) mixed with recently formed spermatozoa, characterizing semicystic spermatogenesis. g: spermatogonia; arrow: spermatozoa; arrow head: tunica albuginea. Staining: a. Toluidine Blue; b, c. Hematoxylin and Eosin.
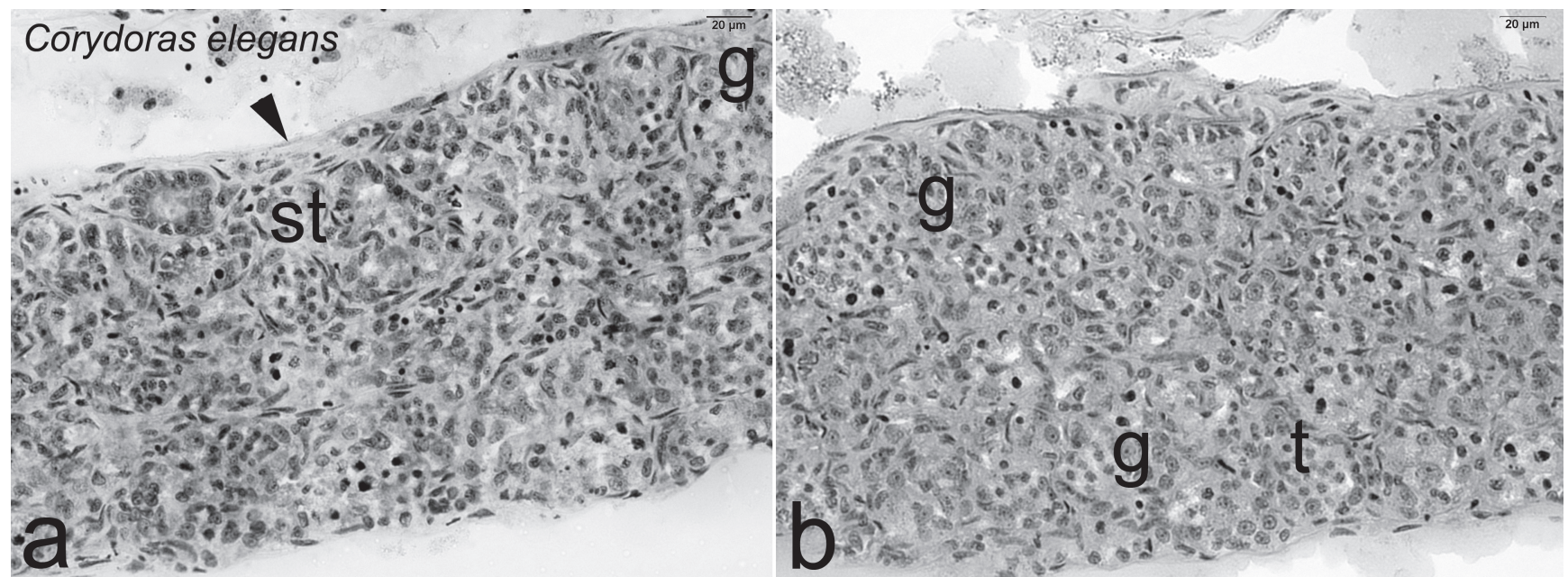

Fig. 15. Photomicrographs of the male reproductive system in C. elegans from Lineage 5. a, b. Anastomosing seminiferous tubules (st), covered by germinal epithelium. g: spermatogonia; t: spermatid; arrow head: tunica albuginea. Staining: a. Toluidine Blue; b. Hematoxylin and Eosin. 

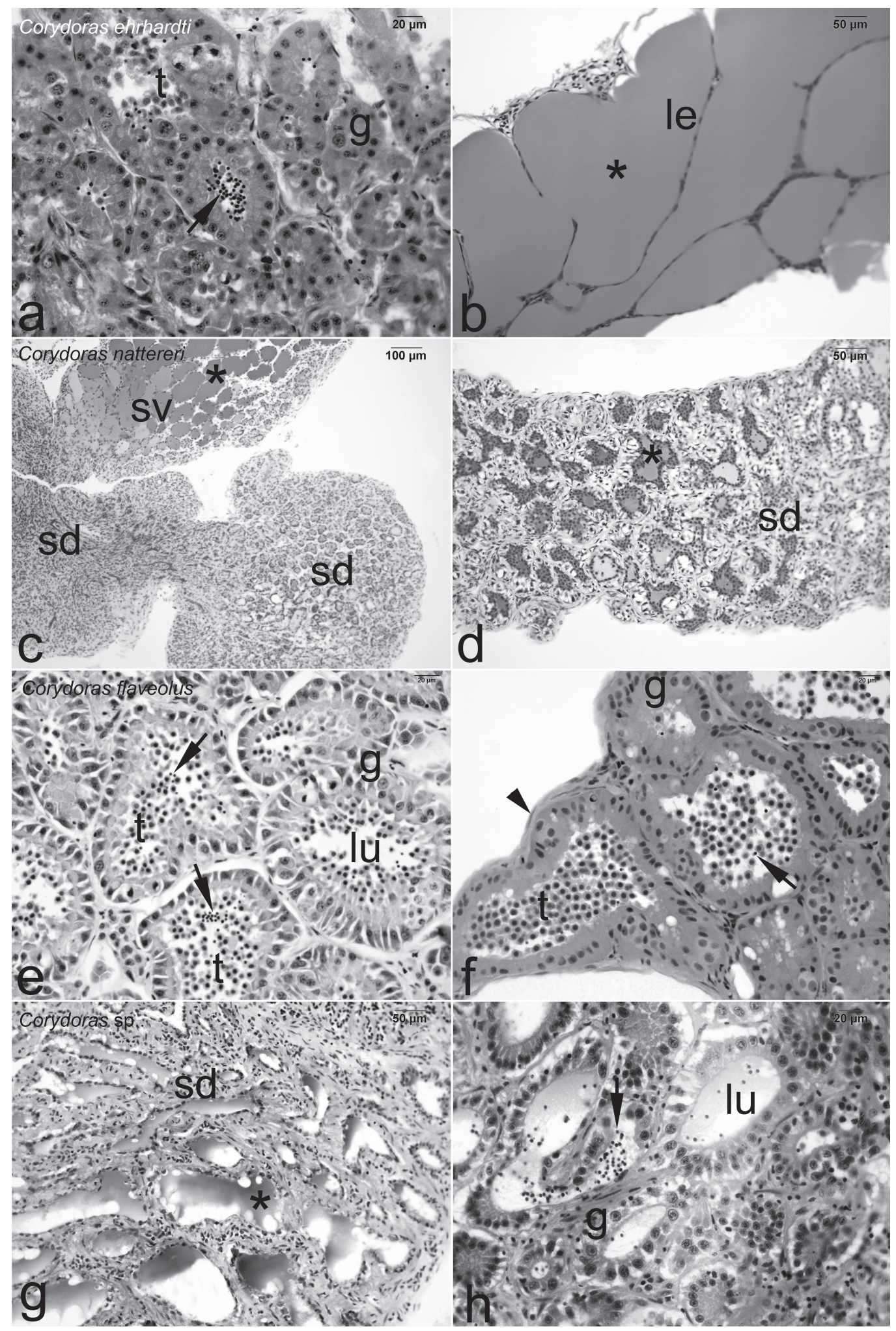

Fig. 16. Photomicrographs of the male reproductive system in species from Lineage 6 , showing anastomosing seminiferous tubules (st), covered by germinal epithelium. a, b. Corydoras ehrhardti; c, d. C. naterreri; e, f. C. flaveolus; g, h. Corydoras sp. Germinal epithelium containing cysts with germinal cells under development until meiosis. Presence on the tubular lumen (lu) of clusters of spermatids ( $t$ ) mixed with recently formed spermatozoa, characterizing semicystic spermatogenesis. b, c. Secretory tubules of the seminal vesicle (sv) with lining epithelium (le), varying from simple cubic to simple squamous. g: spermatogonia; sd: spermatic ducts; asterisk: acidophilic secretion; arrow: spermatozoa; arrow head: tunica albuginea. Staining: a-d, f, h. Hematoxylin and Eosin; e, g. Toluidine Blue. 


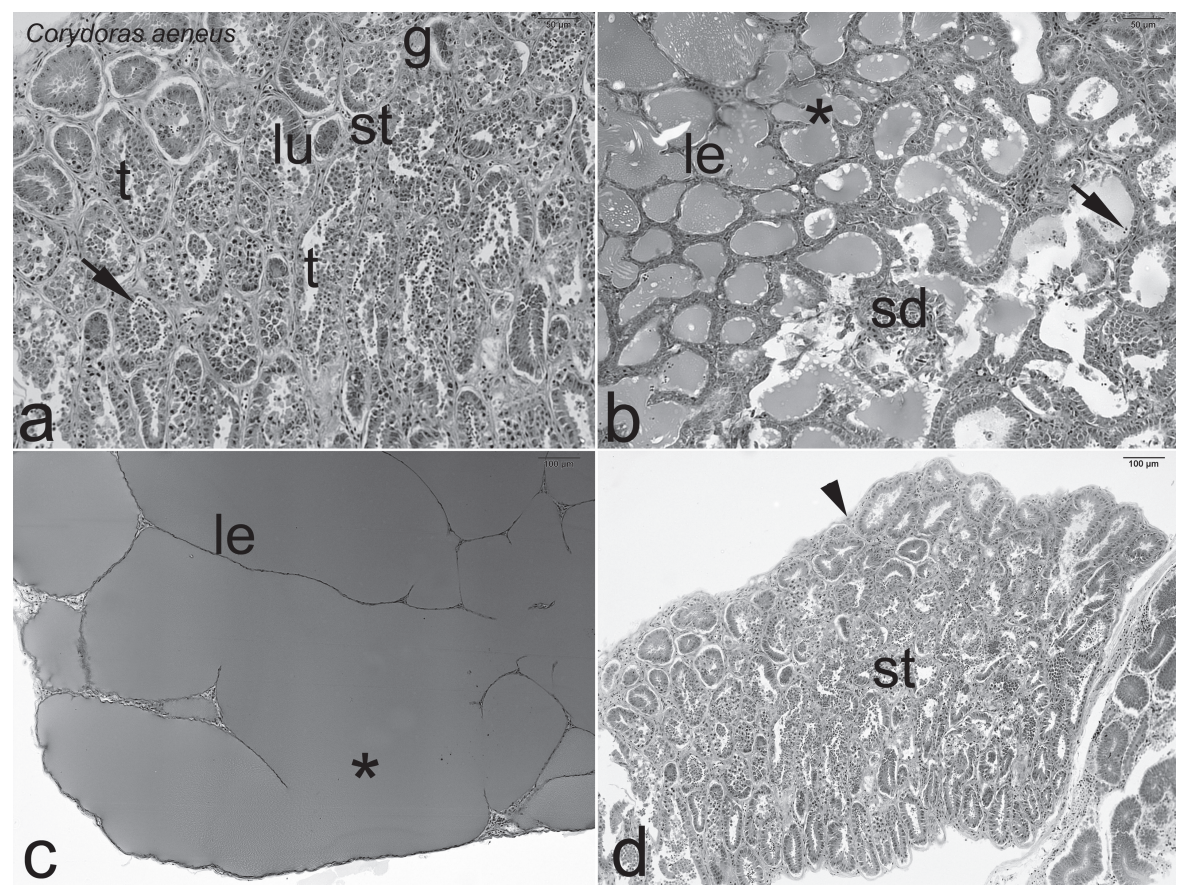

Fig. 17. Photomicrographs of the male reproductive system in C. aeneus from Lineage 7. a, d. Anastomosing seminiferous tubules (st), covered by germinal epithelium. Germinal epithelium containing cysts with germinal cells under development until meiosis. Presence on the tubular lumen (lu) of clusters of spermatids (t) mixed with recently formed spermatozoa, characterizing semicystic spermatogenesis. b. Region of spermatic ducts (sd), containing acidophilic secretion. c. Secretory tubules of the seminal vesicle with lining epithelium (le), varying from simple cubic to simple squamous. g: spermatogonia; asterisk: acidophilic secretion; arrow: spermatozoa; arrow head: tunica albuginea. Staining: Hematoxylin and Eosin.

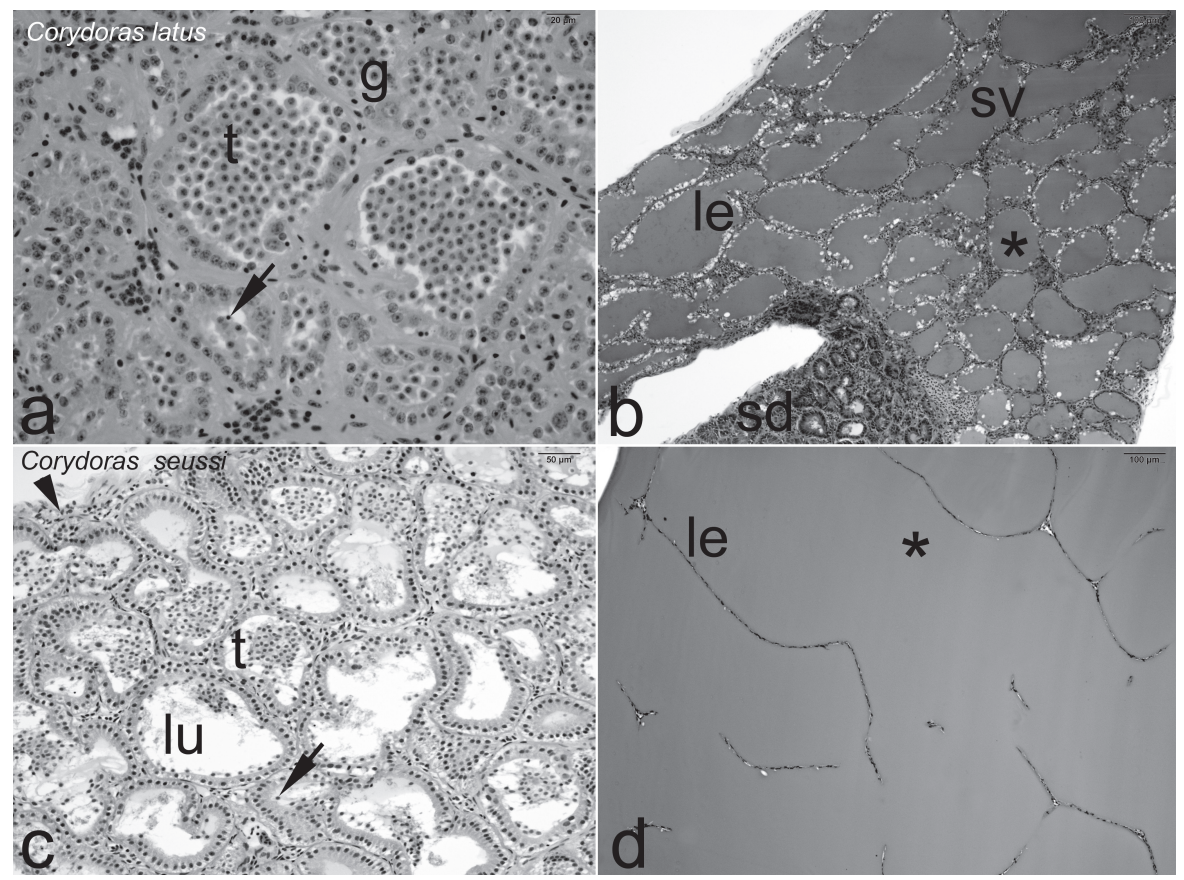

Fig. 18. Photomicrographs of the male reproductive system in species from Lineage 8, showing anastomosing seminiferous tubules (st), covered by germinal epithelium. a, b. Corydoras latus; c, d. C. seussi. Germinal epithelium containing cysts with germinal cells under development until meiosis. Presence on the tubular lumen (lu) of clusters of spermatids (t) mixed with recently formed spermatozoa, characterizing semicystic spermatogenesis. b, d. Region of spermatic ducts (sd), containing acidophilic secretion and secretory tubules of the seminal vesicle (sv) with lining epithelium (le), varying from simple cubic to simple squamous. g: spermatogonia; asterisk: acidophilic secretion; arrow: spermatozoa; arrow head: tunica albuginea. Staining: a, c, d. Hematoxylin and Eosin; b. Toluidine Blue. 

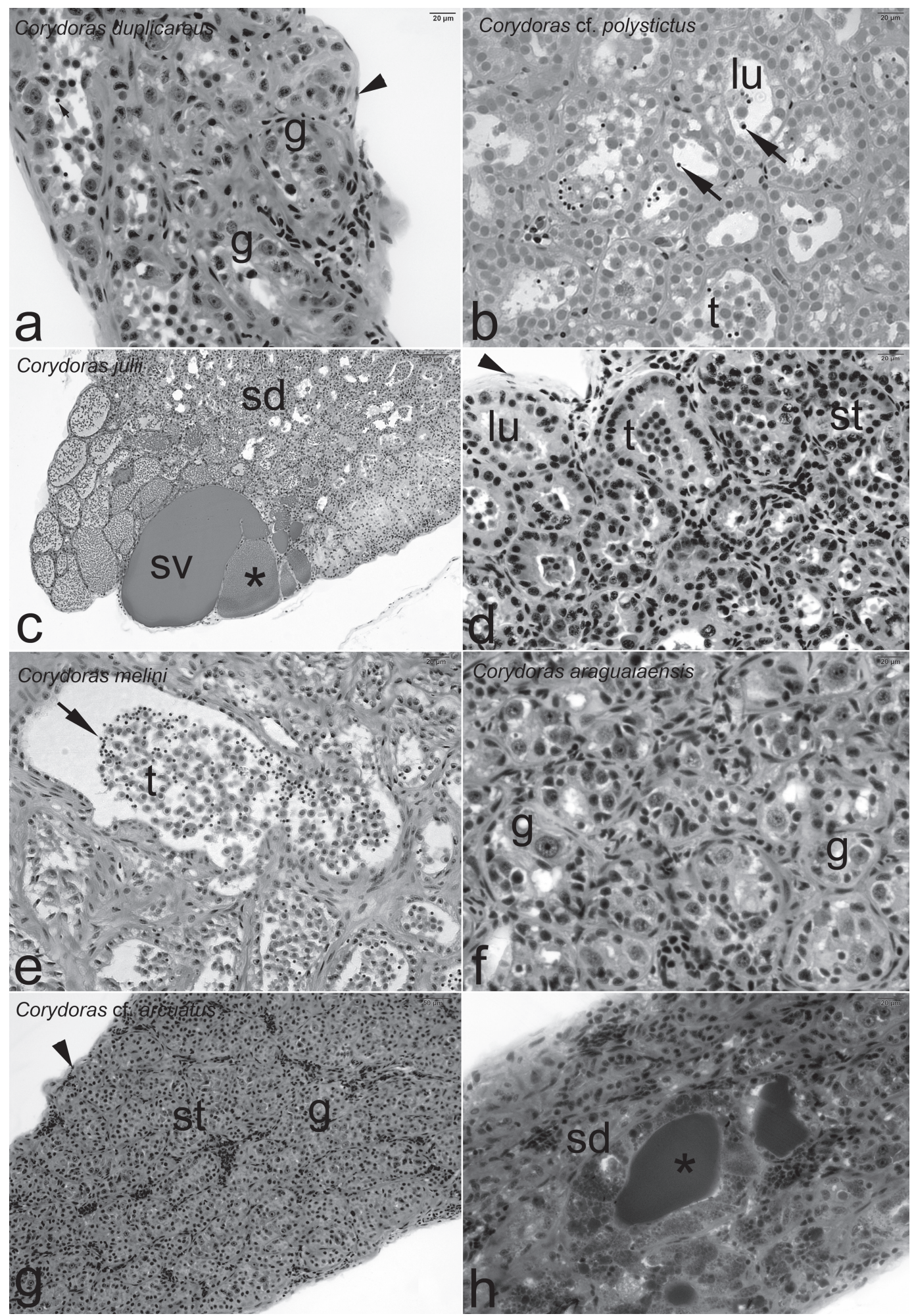

Fig. 19. Photomicrographs of the male reproductive system in species from Lineage 9 , showing anastomosing seminiferous tubules (st), covered by germinal epithelium. a. Corydoras duplicareus; b. C. cf. polystictus; c, d. C. julii; e. C. melini; f. $C$. araguaiaensis; g, h. $C$. cf. arcuatus. Germinal epithelium containing cysts with germinal cells under development until meiosis. Presence on the tubular lumen (lu) of clusters of spermatids (t) mixed with recently formed spermatozoa, characterizing semicystic spermatogenesis. $\mathbf{c}, \mathbf{h}$. Region of spermatic ducts (sd), containing acidophilic secretion and secretory tubules of the seminal vesicle with lining epithelium (le), varying from simple cubic to simple squamous. g: spermatogonia; asterisk: acidophilic secretion; arrow: spermatozoa; arrow head: tunica albuginea. Staining: a, b, c, e. Hematoxylin and Eosin; d. Periodic Acid Schiff; f-h. Toluidine Blue. 

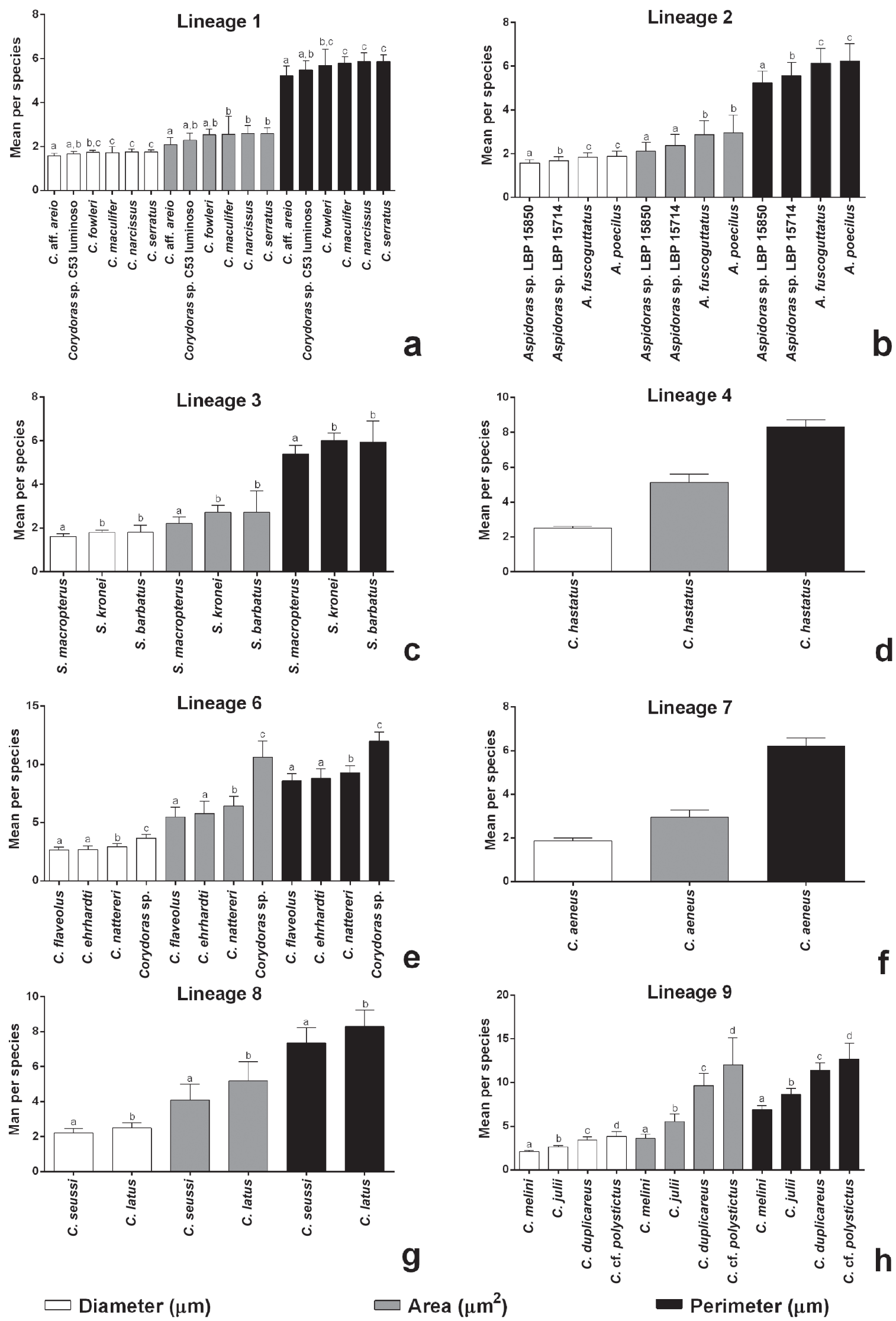

Fig. 20. Comparison among mean $\pm \mathrm{SE}$ of diameter, area and perimeter of sperm heads of the species analyzed by lineage. * Different letters in the same graphic $=p<0.0001$, One-way ANOVA plus Bonferroni's Multiple Comparison Test. 
For lineages 4 (Fig. 20d) and 7 (Fig. 20f), comparative inter-species analysis were not performed due to the sampling of only one species from those lineages.

In lineage 6, the diameter, area and perimeter of the head of spermatozoa from $C$. ehrhardti and C. flaveolus have no significant differences ( $p>0.0001)$, between those species and $C$. nattereri and Corydoras sp. there is difference in the size of heads $(\mathrm{p}<0.0001)$. Between $C$. nattereri and Corydoras sp. there is no difference on the evaluated parameters ( $p>0.0001$ ) (Fig. 20e).

Between species from lineages 8, C. seussi and C. latus, significant differences are observed regarding diameter, area and perimeter of the heads of spermatozoa $(\mathrm{p}<0.0001)$ (Fig. 20g).

In lineage 9, there are significant differences in diameter, area and perimeter of the heads of spermatozoa among all analyzed species, C. melini, C. julii, C. duplicareus and $C$. cf. polystictus $(\mathrm{p}<0.0001)$ (Fig. 20h).

Inter-lineage statistical analysis. The statistical analysis among lineages revealed the same variation observed in the intra-lineage analysis regarding the size of the heads of spermatozoa. Diameter, area and perimeter data of the heads of spermatozoa from the analyzed Corydoradinae species shows that the size of heads on lineages 1, 2 and 3 is significantly smaller $(p<0.0001)$ than the heads of spermatozoa from lineages $4,6,8$ and 9 , which are greater (Figs. 21a-c). The only species where no significant difference is found in the size of the head with species from lineages 1 (C. fowleri, C. maculifer, C. serratus and $C$. narcissus), 2 (A. fuscoguttatus and A. poecilus) and 3 ( $S$. kronei and S. barbatus), is C. aeneus, from lineage 7 (Figs. 21a-c, arrow).

\section{Discussion}

Anatomical and histological data obtained in this study reveal that species of Corydoradinae analyzed share, independently of the lineages they belong, the typical testicular structure observed in fishes and shared by other vertebrates (Grier et al., 2016), consisting in the division on germinal and interstitial compartments (Koulish et al., 2002; Quagio-Grassiotto et al., 2013; Grier et al., 2016).

In Teleostei, the organization of the germinal compartment inside testes may be in lobules or tubules (Grier, 1993; Parenti, Grier, 2004), based on the shape and the way that this compartment ends at the periphery of the organ (Grier, 1993). In the analyzed Corydoradinae from different lineages, the observed testicular organization is of the anastomosing tubular type (Grier, 1993; Grier, Uribe Aranzábal, 2009).

Regarding spermatogenesis, all analyzed species of Corydoradinae independently of the allocated lineage have this process occurs outside the cysts suggests that spermatogenesis in these species is of the semicystic type, according to Mattei et al. (1993). Ultrastructural analysis of testes from Corydoradinae subfamily, performed by Spadella et al. (2007), also reveals the presence of spermatids along with spermatozoa in the lumen of seminiferous tubules, suggesting the semicystic type of spermatogenesis, corroborating with results from this study.

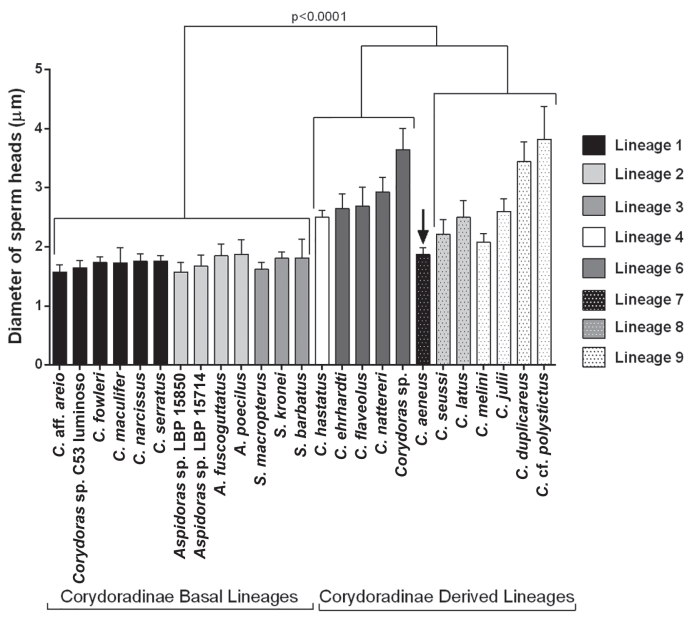

a
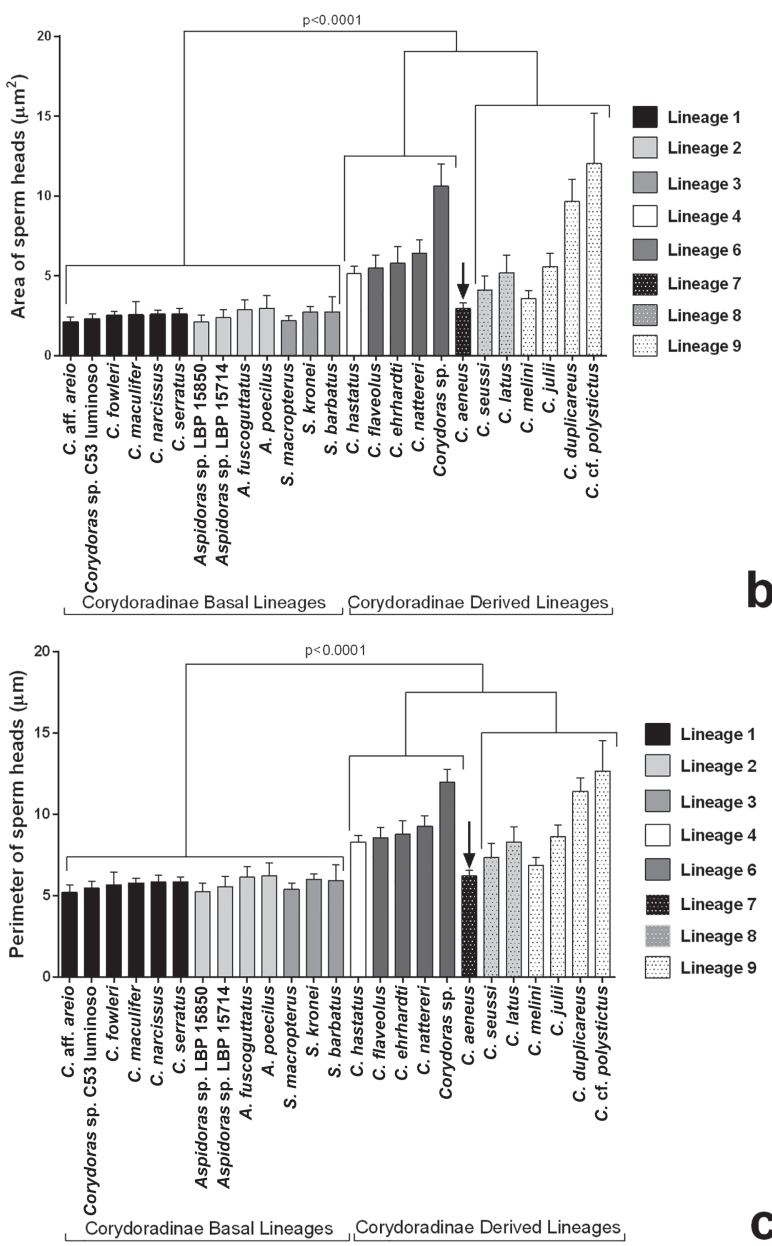

Fig. 21. Comparison among lineages proposed relative to mean $\pm \mathrm{SE}$ of the diameter (a), area (b) and perimeter (c) of sperm heads of the analyzed species. Significant statistically differences $=p<0.0001$, One-way ANOVA plus Bonferroni's Multiple Comparison Test. 
The transformation of spermatids in spermatozoa involves morphological changes such as the formation of the spermatozoon head, condensation of chromatin, formation of the midpiece, loss of cytoplasm and development of the flagellum (Pudney, 1995; Miura, 1999). At the beginning of the process, spermatids are haploids, no longer dividing and having spherical shape. Along the spermiogenesis, the spermatids nuclei become smaller as the degree of chromatin condensation increases. Besides, those cells become mobile due to the development of the flagellum and retain mitochondria, which will be located in the midpiece of the future spermatozoon. The excess of cytoplasm of spermatids during their differentiation creates the residual body, which is phagocytosed by the Sertoli cell (Grier, Uribe Aranzábal, 2009).

During spermiogenesis, the chromatin of spermatids under differentiation suffers a noteworthy condensation, with the progressive replacement of basic nuclear proteins allowing the occurrence of the normal process of chromatin condensation and the functional development of spermatozoa. Along the development of spermatozoa, histones, nuclear proteins that bind to DNA in the initial spermatids are removed and substituted in the final stage of maturation by one of the three kinds of proteins: spermatozoon-specific histones, proteins similar to protamines or true protamines (Balhorns, 2007). Those three classes of chromosomal proteins involved in the structuration of mature spermatozoa chromatin are generically known as Sperm Nuclear Basic Proteins $\left(\mathrm{SNBP}_{\mathrm{s}}\right)$, whereas in fish, Teleostei represent the most diverse group, having the three types of $\mathrm{SNBP}_{\mathrm{s}}$ (Ausió et al., 2007).

Protamines constitute a family of small proteins, rich in arginine, which are produced on polyribosomes present on the cytoplasm of spermatids during the last stage of differentiation. Those proteins bind to DNA, promoting the condensation of the genome of spermatids, making it genetically inactive (Balhorns, 2007). As this compaction of chromatin happens, by the total or partial replacement of histones by protamines, a high degree of condensation is reached with the consequent differentiation of the nuclei of spermatozoa.

The presence of accessory glands in the male reproductive system was observed at least one species of each lineage analyzed in this study. According to the definition of Lahnsteiner, Patzner (2009), these glands may be classified as "seminal vesicles", since they are lobular glands that debouch on the spermatic ducts.

Presence of these differentiated regions with secretory activity is known in other representatives of Callichthyidae (Loir et al., 1989; Mansour, Lahnsteiner, 2003; Mazzoldi et al., 2007). In particular for Corydoradinae, in Corydoras sp. (Loir et al., 1989), in C. aeneus (Franceschini-Vicentini et al., 2007) and in C. bondi, C. potaroensis e C. ehrhardti (Mazzoldi et al., 2007), the presence of secretory mass located on the ventral side of the testes was observed, corroborating the results of this study.
Regarding the presence and localization of the seminal vesicle on the testes and the presence and shape of the genital papilla in males, the analyzed species from Corydoradinae lineages have divergences. Considering an inter-generic comparison in Corydoradinae, the genera Aspidoras and Scleromystax have characteristics of seminal vesicles and genital papilla more similar than those presents on species of Corydoras. These findings shows that the species from Aspidoras and Scleromystax analyzed are more related, corroborating the hypothesis of relationship inside the Corydoradinae subfamily proposed by Britto (2003b).

Although the species of Corydoradinae analyzed in this study share characters such as testes with anastomosed tubular organization and the occurrence of semicystic spermatogenesis, reinforcing the hypothesis that the subfamily constitutes a monophyletic group, as previously postulated (Reis, 1998, 2003; Britto, 2003a; ShimabukuroDias et al., 2004) they are not useful to distinguish the different lineages. Then, morphological data obtained are not enough to identify particular reproductive characteristics for different lineages supporting the recent proposal by Alexandrou et al. (2011), since variations were also found on the lineages characteristics.

Differently, morphometric data obtained from eight out of the nine proposed lineages, revealed great congruence with the proposal from Alexandrou et al. (2011) for Corydoradinae.

Based on the intra-lineage statistical analysis, the data shown significant differences in the size of the heads of spermatozoa between species from the same lineage. This may be justified by data of Alexandrou et al. (2011) that demonstrate significant variation on the genome size inside the lineages, especially between sister species. Thus, this variation found in the DNA content present on the nucleus between the species of a lineage, also reflects on the spermatogenesis and spermiogenesis, generating spermatozoa with different sizes of heads. Besides, in species where is found significant difference on the size of the heads of spermatozoa, different DNA content is also observed.

The inter-lineage statistical analysis revealed the same variation observed in the intra-lineage analysis regarding the size of the heads of spermatozoa. In this variation, the size of the genome in each one of the nine lineages proposed for Corydoradinae must be considered. Thus, the phylogeny of the nine lineages of Corydoradinae proposed by Alexandrou et al. (2011), reconstructing the size of the genome per lineage, evidences that within the basal lineages of Corydoradinae (lineages 1,2 and 3), the haploid DNA content (Haploid C-value) ranges between 0.51 and $0.94 \mathrm{pg}$, while the derived lineages (4 to 9) have greater variation in $\mathrm{C}$-value, from 1.42 to $4.8 \mathrm{pg}$. The correspondence between the size of genome and the size of the head of spermatozoa obtained in this study was corroborated with the findings of Alexandrou et al. (2011), since the species with spermatozoa of smaller sizes are the ones with a conserved pattern of the evolution of genome 
size (basal lineages 1, 2, 3). Spermatozoa with larger heads are the ones from species with significant genomic expansion (derived lineages 4 to 9 ).

Corydoras aeneus, from lineage 7 was the only species where no significant difference is found in the size of the head with species from lineages 1, 2 and 3. According to Alexandrou et al. (2011), the variations in the size of genome are more pronounced on lineages 7 and 9. Despite this $C$. aeneus is not one of the species from lineage 7 that has extensive DNA content $($ Haploid C-value $=1.39 \mathrm{pg}$, Oliveira et al., 1993), which may be evidenced on the phylogeny proposed by the author. Thus, when compared with species from lineages 1, 2 and 3 with spermatozoa of heads smaller and genomic size also smaller, C. aeneus is not different.

We proved that there is correlation between variations in DNA content and size of the heads of spermatozoa. It is evidenced that, on basal lineages of Corydoradinae, with smaller size of genome, the heads of spermatozoa are also smaller and little variable, while on derived lineages, whose DNA content is larger, the size of the heads reflects this condition.

Finally, morphometry reveals that there is influence of the size of genome over the shape of the heads of spermatozoa from the analyzed species, providing additional support for the definition of the proposal of nine lineages for Corydoradinae. It is expected that this study contributes for knowing the real extension of the structural, morphometric and organizational variability of the male reproductive system and how much they reflect the relationships between Corydoradinae.

\section{Acknowledgments}

This research was supported by the Brazilian agency grant \# 2009/14072-8, grant \# 2012/10065-0, Fundação de Amparo à Pesquisa do Estado de São Paulo (FAPESP).

\section{References}

Alexandrou MA. Mechanisms of speciation and coexistence in Corydoradinae catfishes. [PhD Thesis]. Bangor: Bangor University; 2011.

Alexandrou MA, Oliveira C, Maillard M, McGill RAR, Newton J, Creer S, Taylor MI. Competition and phylogeny determine community structure in Mullerian co-mimics. Nature. 2011; 469(7328):84-88.

Alexandrou MA, Taylor MI. Evolution, ecology and taxonomy of the Corydoradinae revisited. In: Fuller IAM, Evers HG, editors. Identifying Corydoradinae catfish: Aspidoras, Brochis, Corydoras, Scleromystax, C-numbers \& CW-numbers: supplement 1. Kidderminster: Ian Fuller Enterprises; 2011. p.101-114.

Arratia G, Kapoor BG, Chardon M, Diogo R. Catfishes. Enfield (NH): Science Publishers; 2003.

Ausió J, Eirín-López JM, Frehlick LJ. Evolution of vertebrate chromosomal sperm proteins: implications for fertility and sperm competition. Soc Reprod Fertil Suppl. 2007; 65(2007):63-79.
Balhorns R. The protamine family of sperm nuclear proteins. Genome Biol. 2007; 8(9):227[9p.].

Britto MR. Análise filogenética da ordem Siluriformes com ênfase nas relações da superfamília Loricarioidea (Teleostei: Ostariophysi). [PhD Thesis]. São Paulo, SP: Universidade de São Paulo; 2003a.

Britto MR. Phylogeny of the subfamily Corydoradinae Hoedeman, 1952 (Siluriformes: Callichthyidae), with a definition of its genera. Proc Acad Nat Sci Philadelphia. 2003b; 153(1):119-54.

Burgess WE. An atlas of freshwater and marine catfishes: a preliminary survey of Siluriformes. New Jersey: T.F.H Publications; 1989.

Eschmeyer WN, Fong JD, editors. Species by Family/Subfamily [Internet]. San Francisco: California Academy of Science; 2016 [updated 2016 March 10; cited 2016 Dec 13]. Available from: http://researcharchive.calacademy.org/research/ichthyology/ catalog/SpeciesByFamily.asp

Franceschini-Vicentini IB, Papa LP, Bombonato MTS, Vicentini CA, Ribeiro K, Orsi AM. A histological study of the seminal vesicle of the armoured catfish Corydoras aeneus. Anat Histol Embryol. 2007; 36(2):111-15.

Ferraris CJ, Jr. Ckecklist of catfishes, recent and fossil (Osteichthyes: Siluriformes), and catalogue of siluriform primary types. Zootaxa. 2007; 2007(1418):1-628.

Gallego V, Peñaranda DS, Marco-Jiménez F, Mazzeo I, Pérez L, Asturiano JF. Comparison of two techniques for the morphometry study on gilthead seabream (Sparus aurata) spermatozoa and evaluation of changes induced by cryopreservation. Theriogenology. 2012; 77(6):1078-87.

Grier HJ. Comparative organization of Sertoli cells including the Sertoli cell barrier. In: Russell LD, Griswold MD, editors. The Sertoli cell. Clearwater (FL): Cache River Press; 1993. p.704-739.

Grier HJ, Uribe Aranzábal MC. The testis and spermatogenesis in teleosts. In: Jamieson BGM, editor. Reproductive biology and phylogeny of fishes (agnathans and bony fishes): phylogeny, reproductive system, viviparity, spermatozoa. Enfield (NH): Science Publishers; 2009. (Reproductive Biology and Phylogeny; vol. 8A). p.119-142.

Grier HJ, Uribe MC, Lo Nostro FL, Mims SD, Parenti LR. Conserved from and function of the germinal epithelium through 500 milion years of vertebrate evolution. J Morphol. 2016; 277(8):1014-44.

Lahnsteiner F, Patzner RA. Male reproductive system: spermatic duct and accessory organs of the testis. In: Jamieson BGM, editor. Reproductive Biology and Phylogeny of Fishes (agnathans and bony Fishes). Endfield (NH): Science Publishers; 2009. p. 143-186.

Koulish S, Kramer CR, Grier HJ. Organization of the male gonad in a protogynous fish, Thalassoma bifasciatum (Teleostei: Labridae). J Morphol. 2002; 254(3):292-311.

Loir M, Cauty C, Planquette P, Le Bail PY. Comparative study of the male reproductive tract in seven families of SouthAmerican catfishes. Aquatic Living Resour. 1989; 2(1):45-56.

Mansour N, Lahnsteiner E. Morphology of the male genitalia and sperm fine structure in siluroid fish. J Submicrosc Cytol Pathol. $2003 ; 35(3): 277-85$. 
Mazzoldi C, Lorenzi V, Rasotto MB. Variation of male reproductive apparatus in relation to fertilization modalities in the catfish families Auchenipteridae and Callichthyidae (Teleostei: Siluriformes). J Fish Biol. 2007; 70(1):243-56.

Mattei X, Siau Y, Thiaw OT, Thiam D. Peculiarities in the organization of testis of Ophidion sp. (Pisces: Teleostei): evidence for two types of spermatogenesis in teleost fish. J Fish Biol. 1993; 43(6):931-37.

Miura T. Spermatogenetic cycle in fish. In: Knobil E, Neill JD, editors. Encyclopedia of Reproduction. San Diego: Academic Press; 1999. p.571-578.

Nelson JS, Grande TC, Wilson MVH. Fishes of the world. 5th ed. Hoboken (NJ): John Wiley \& Sons; 2016.

Oliveira C, Almeida-Toledo LF, Mori L, Toledo-Filho SA. Extensive chromosomal rearrangements and nuclear DNA content changes in the evolution of the armoured catfishes genus Corydoras (Pisces, Siluriformes, Callichthyidae). J Fish Biol. 1992; 40(3):419-31.

Oliveira C, Almeida-Toledo LF, Mori L, Toledo-Filho SA. Cytogenetic and DNA content in six genera of the family Callichthyidae (Pisces, Siluriformes). Caryologia. 1993; 46(23):171-88.

Parenti LR, Grier HJ. Evolution and phylogeny of gonad morphology in bony fishes. Integr Comp Biol. 2004; 44(5):333-48.

de Pinna MCC. Phylogenetic relationships of Neotropical Siluriformes (Teleostei: Ostariophysi): historical overview and synthesis of hypotheses. In: Malabarba LR, Reis RE, Vari RP, Lucena ZMS, Lucena CAS, editors. Phylogeny and classification of Neotropical fishes. Porto Alegre: Edipucrs; 1998. p.279-330.
Pudney J. Spermatogenesis in nonmammalian vertebrates. Microsc Res Tech. 1995; 32(6):459-97.

Quagio-Grassiotto I, Wildner DD, Ishiba R. Gametogênese de peixes: aspectos relevantes para o manejo reprodutivo. Rev Bras Reprod Anim. 2013; 37(2):181-91.

Reis RE. Anatomy and phylogenetic analysis of the Neotropical callichthyid catfishes (Ostariophysi, Siluriformes). Zool J Linnean Soc. 1998; 124(2):105-68.

Reis RE. Family Callichthyidae (Armored catfishes). In: Reis RE, Kullander SO, Ferraris CJ, Jr., organizers. Check list of the freshwater fishes of South and Central America. Porto Alegre: Edipucrs; 2003. p.291-309.

Shimabukuro-Dias CK, Oliveira C, Reis RE, Foresti F. Molecular phylogeny of the armored catfish family Callichthyidae (Ostariophysi, Siluriformes). Mol Phylogenet Evol. 2004; 32(1):152-63.

Spadella MA, Oliveira C, Quagio-Grassiotto I. Comparative analysis of the spermiogenesis and sperm ultrastructure in Callichthyidae (Teleostei: Ostariophysi: Siluriformes). Neotrop Ichthyol. 2007; 5(3):337-50.

Teugels GG. Taxonomy, phylogeny and biogeography of catfishes (Ostariophysi, Siluroidei): an overview. Aquat Living Resour. 1996; 9:9-34.
Submitted September 29, 2015 Accepted March 3, 2017 by Marcelo Britto 
